\title{
Aerosol seasonal variability over the Mediterranean region and relative impact of maritime, continental and Saharan dust particles over the basin from MODIS data in the year 2001
}

\author{
F. Barnaba and G. P. Gobbi \\ Istituto di Scienze dell'Atmosfera e del Clima, ISAC-CNR, Via Fosso del Cavaliere, 100, 00133, Roma, Italy \\ Received: 17 May 2004 - Published in Atmos. Chem. Phys. Discuss.: 4 August 2004 \\ Revised: 8 November 2004 - Accepted: 18 November 2004 - Published: 30 November 2004
}

\begin{abstract}
The one-year (2001) record of aerosol data from the space borne Moderate Resolution Imaging Spectroradiometer (MODIS) is analyzed focusing on the Mediterranean region. The MODIS aerosol optical thickness standard product (AOT at $550 \mathrm{~nm}$ ) provided over both land and ocean is employed to evaluate the seasonal and spatial variability of the atmospheric particulate over the region. Expected accuracy of the MODIS AOT is $( \pm 0.05 \pm 0.2 \times$ AOT $)$ over land and $( \pm 0.03 \pm 0.05 \times$ AOT $)$ over ocean. The seasonal analysis reveals a significant AOT variability all over the region, with minimum values in Winter $(\mathrm{AOT}<0.15)$ and maximum in Summer (AOT>0.2). The spatial variability is also found to be considerable, particularly over land. The impact of some major urban sites and industrialized areas is detectable. For the sole Mediterranean basin, a method (aerosol mask) was implemented to separate the contribution of maritime, continental and desert dust aerosol to the total AOT. Input of both continental and desert dust particles is well captured, showing North-to-South and South-to-North AOT gradients, respectively. A quantitative summary of the AOT seasonal and regional variability is given for different sectors of the Mediterranean basin. Results of this summary were also used to test the aerosol mask assumptions and indicate the method adopted to be suitable for the aerosol type selection. Estimates of the atmospheric aerosol mass load were performed employing specifically-derived massto-extinction efficiencies $(\alpha)$. For each aerosol type, a reliable mean $\alpha$ value was determined on the basis of both lidar measurements of extinction and aerosol models. These estimates indicate a total of 43 Mtons of desert dust suspended over the basin during 2001. A comparable value is derived for maritime aerosol. Opposite to the dust case, a minor seasonal variability (within 15\%) of maritime aerosol mass is
\end{abstract}

Correspondence to: F. Barnaba

(f.barnaba@isac.cnr.it) found. This latter result is considered a further check of the suitability of the methodology adopted to separate, on the basis of MODIS data, the three aerosol types which dominate the Mediterranean region.

\section{Introduction}

The great effort spent over the last decade by the scientific community to investigate atmospheric particulate matter reflects the importance attributed to aerosol in controlling the Earth's climate (e.g. Penner et al., 2001). Major advancements in the field have been fostered by a new generation of space based instruments (e.g. ATSR-2 on board the ESA-ERS2, MODIS and MISR on board the NASA Terra, POLDER on board the ADEOS), specifically developed to facilitate detection and characterization of atmospheric aerosols (e.g. King et al., 1999). A large amount of space-retrieved aerosol data has been produced in recent years and, after the initial period of quality checking (e.g. Chu et al., 2002; Remer et al., 2002; Chu et al., 2003; Levy et al., 2003; Liu et al., 2004), validated information is now becoming available. Even though further improvement of aerosol dedicated instruments and inversion techniques is still needed, it is important to exploit the large, routinely available set of data, particularly considering the unique potential of space-based observations in terms of spatial coverage.

On this basis, a one-year-dataset (2001) of the aerosol optical thickness operational product (AOT) from the Moderateresolution Imaging Spectroradiometer (MODIS, on board the NASA platform Terra) has been employed and analyzed to get a picture of the aerosol seasonal and regional variability over the Mediterranean region. This study was performed in combination with the analysis by Gobbi et al. (2004) in

(C) 2004 Author(s). This work is licensed under a Creative Commons License. 
which the record of lidar soundings collected in the year 2001 was used to characterize the seasonal variability of the aerosol vertical distribution over Rome (Italy), as representative of Central Mediterranean conditions.

The Mediterranean represents a unique area in terms of suspended particulate matter. Bounded to the north by the European continent and to the south by the North Africa arid regions, it is largely affected by both Saharan dust, anthropogenic aerosols and, of course, maritime aerosols. Transport of Saharan dust from the North African coasts to the Mediterranean and Europe has been widely investigated (either as long term analyses or as "case studies") employing in situ samplings (e.g. Molinaroli et al., 1993; Loye-Pilot and Martin, 1996; Avila et al., 1998; Kubilay et al., 2000; Collaud Coen et al., 2003), lidar (e.g. Hamonou et al., 1999; Gobbi et al., 2000; Di Sarra, et al., 2001; Muller et al., 2003; De Tomasi et al., 2003; Dulac and Chazette, 2003; Gobbi et al., 2004) and satellite observations (e.g. Dulac et al., 1992a; Moulin et al., 1998; Israelevich et al., 2002). Conversely, studies of the export of particles from the European continent (i.e. mainly pollution-related cases) to the Mediterranean Sea are still limited. However, a growing interest in this topic is now emerging. A recent international effort to quantify the impact of anthropogenic emissions on the natural background of the Mediterranean environment is represented by the Mediterranean Intensive Oxidant Study (MINOS). Largely based on experimental results, the MINOS project highlighted the important role of pollutants in the summertime Mediterranean atmosphere (e.g. Lelieveld, 2002). Models have also been usefully employed to investigate the export pathways of air pollution from Europe (e.g. Stohl et al., 2002; Duncan and Bey, 2004). Still, Duncan and Bey (2004) point out the current lack of observations of pollution-related parameters to be compared to model results in the European region.

The strength of the dust outbreaks over the Mediterranean tends to facilitate the Saharan dust detection by both ground and space based observations, allowing the quantification of its transport and of its optical and microphysical properties. As opposite to Saharan dust, investigation of the export of particulate matter from the industrialized countries surrounding the Mediterranean (in the following referred to as "continental aerosols") is complicated by the fact that an extremely large number of species and gas precursors (including inorganic and organic compounds) contribute to it. In analyzing space-based observations, such a complexity can partly be reduced focusing on some specific physical and optical properties of these particles. In fact, continental aerosol is recognized to be mainly composed of fine particles $(\mathrm{r}<0.6 \mu \mathrm{m})$ so that their optical properties are strongly dominated by the aerosol fine fraction (e.g. Dubovik et al., 2002; Kaufman et al., 2002).

In this study we perform a seasonal analysis of the MODIS-derived AOT field over the Mediterranean region (land and ocean) to investigate the aerosol's seasonal and re- gional patterns. Moreover, we evaluate the contribution to the total AOT of continental and desert-dust aerosols over the Mediterranean basin (in addition to the maritime aerosol one). This result is obtained by implementing a simple scheme (hereafter referred to as "aerosol mask") that combines the MODIS operational retrieval of the aerosol optical thickness with a second MODIS product (the fine fraction) indicating the relative contribution of the fine particles to the total AOT. The aerosol mask scheme is described in Sect. 2, together with examples of its application to specific case studies. In Sect. 3, results are presented in terms of seasonally averaged maps of both total AOT and relative AOT contributions of maritime, continental and desert dust aerosols. A summary of the aerosol seasonal variability is then given in Sect. 3.1, where regional analysis is performed by dividing the Mediterranean basin into ten different sectors. Estimates of the aerosol mass load in the ten sectors of the Mediterranean basin are then given in Sect. 3.2. These have been obtained, for the three different aerosol types, employing appropriate mass-to-extinction efficiencies $(\alpha=$ AOT/M) derived from lidar observations and model-based results. In order to focus Sect. 3.2 on the presentation and discussion of results, the procedure employed to derive the $\alpha$ factors is described in Appendix A. In Sect. 3.2, the Mediterranean sectors summary is also employed as a test of the aerosol mask capability to actually discriminate between the three aerosol types addressed in this study.

\section{Methods}

The Moderate Resolution Imaging Spectroradiometer (MODIS) was launched in December 1999 on the polar orbiting NASA-EOS Terra spacecraft. Terra's sunsynchronous orbit has a dayside equatorial 10:30 am local crossing time. Since February 2000, MODIS data are acquired in 36 spectral bands from the visible to the thermal infrared. A nearly global image is produced daily thanks to the instrument scanning angle of $110^{\circ}$ (i.e. swath width of $2330 \mathrm{~km}$ ). Aerosol retrievals from MODIS data are performed over land and ocean surfaces by means of two separate algorithms thoroughly described in Kaufman and Tanré (1998). Aerosol products are stored in MODIS Level 2 (MOD04L2) files, each corresponding to five-minute-acquisition along the satellite orbit. The two aerosol products employed in this study are: 1) the optical thickness at $550 \mathrm{~nm}$ (MOD04_L2 Scientific Data Set: Optical_Depth_Land_And_Ocean, in the following referred to as AOT) and 2) the fine fraction (MOD04_L2 Scientific Data Set: Optical_Depth_Ratio_Small_Ocean, in the following referred to as FF). This latter is defined as the ratio of optical thickness of small mode vs effective optical thickness at $550 \mathrm{~nm}$. Both products are given at a spatial resolution of $10 \times 10 \mathrm{~km}$ (at nadir). The AOT is provided over both land and ocean merging the two different 
retrievals developed for the two different surfaces. The fine fraction product is only operational over ocean surfaces (although Chu et al., (2003) showed that separation of fine and coarse particles over land is possible by comparing the path radiances at 660 and $470 \mathrm{~nm}$ ). As discussed in detail in the MODIS aerosol products validation studies, a different accuracy is associated to the MODIS AOT retrievals over land $\left(\triangle \mathrm{AOT}_{\text {land }}= \pm 0.05 \pm 0.2 \mathrm{AOT}\right.$; Chu et al., 2002 ; $\mathrm{Chu}$ et al., 2003) and over ocean $\left(\triangle \mathrm{AOT}_{\text {ocean }}= \pm 0.03 \pm 0.05\right.$ AOT; Remer et al., 2002). Over land, errors larger than $\Delta \mathrm{AOT}_{\text {land }}$ can be found in coastal zones due to sub-pixel water contamination. This effect tends to produce an AOT overestimation (Chu et al., 2003). Over ocean, the validation by Remer et al. (2002) shows the major uncertainties to occur at small optical thickness, when the aerosol contribution to the measured radiance is low and surface contributions (as foam and water color) can be misinterpreted. Similarly, a significant water color contribution can reduce the ocean AOT retrieval quality in coastal areas. Largely based on Mediterranean test sites, the study by Remer et al. (2002) also indicates the particle size-dependent parameters (as the FF) to be retrieved with an accuracy within $\pm 25 \%$.

In this work, daily MODIS observations over the Mediterranean region (about three L2 files per day) were collected for the whole year 2001 (except for the period 15 June-3 July, due to instrumental problems). For each L2 file, AOT and $\mathrm{FF}$ data were binned into a $0.1^{\circ} \times 0.1^{\circ}$ grid (i.e. about $10 \times 10 \mathrm{~km}$ pixels), corresponding to the geographical area within the latitude and longitude ranges $30^{\circ} \mathrm{N}-50^{\circ} \mathrm{N}$ and $10^{\circ} \mathrm{W}-35^{\circ} \mathrm{E}$, respectively. The derived 0.1 -degree-binned AOT data were then averaged on a seasonal basis, the four seasons being defined as DJF (December-January-February, i.e. Winter), MAM (March-April-May, i.e. Spring), JJA (June-July-August, i.e. Summer), SON (September-OctoberNovember, i.e. Fall). Moreover, for each L2 file, AOT and FF data were jointly analyzed (in co-located 0.1-degree-bins) to distinguish between maritime, continental and desert dust aerosol following the method described in Sect. 2.1. Then, for each season, the contribution of the three aerosol types to the total, mean AOT was computed.

\subsection{The aerosol mask}

In order to reduce the complexity of the atmospheric aerosol system, some general categories can be identified on the basis of the particles origin. In particular, over the Mediterranean, three main aerosol types are expected to dominate the atmospheric load: 1) maritime aerosol produced on the sea surface by winds; 2) continental aerosol originating in the industrialized countries surrounding the Mediterranean Sea from both anthropogenic and non-anthropogenic activities (e.g. fossil fuel combustion, industrial activity, soil erosion); 3) desert dust lifted into the Mediterranean atmosphere from the North African arid regions. Produced by such different mechanisms, these aerosol types generally show sub-

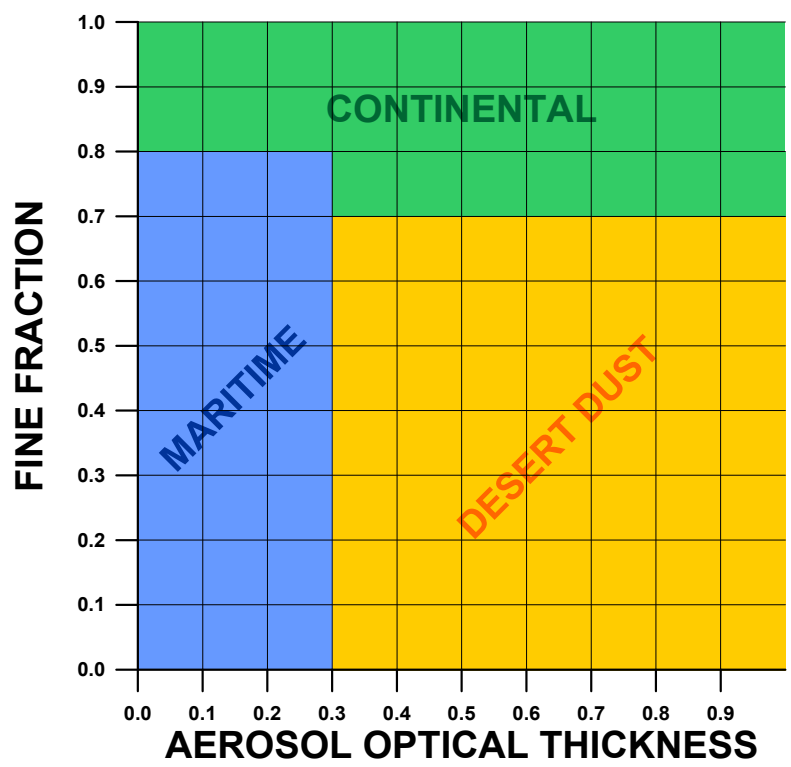

Fig. 1. Aerosol mask defining the regions corresponding to continental, desert dust and maritime aerosol (green, yellow and blue areas, respectively) in the Fine Fraction (FF) versus Aerosol Optical Thickness (AOT) space.

stantially different optical and physical properties (e.g. Kaufman et al., 2002). In fact, in urban/industrial conditions, optical properties are dominated by fine particles (e.g. Remer and Kaufman, 1998; Dubovik et al., 2002) while, in the presence of desert dust, these are strongly dominated by coarse particles. In maritime conditions, the relative contribution of coarse particles, although variable (Smirnov et al., 2002), is generally higher than in urban/industrial conditions and lower than for desert dust (e.g. Dubovik et al., 2002).

Following the previous considerations, we implemented a simple method (aerosol mask) to separate the contribution of the three aerosol types over the Mediterranean Sea, based on the combination of the MODIS AOT and FF data. In particular, we proceeded with defining which regions of the FF vs. AOT space would be peculiar to the three aerosol types. The following considerations were taken into account to define the three regions limits shown in Fig. 1 (blue, green and yellow portions corresponding to maritime, continental and desert dust aerosol, respectively). As opposite to remote oceanic regions, it is particularly difficult to define "pure maritime conditions" in inland seas as the Mediterranean. Avoiding the most turbid conditions (associated to Saharan dust transport), in the Mediterranean one can distinguish between clean atmospheres, when AOT values are close to the ones registered in background oceanic regions (i.e. AOT $\leq 0.1$ ), and "standard" atmospheres, wherein the mean AOT is in the range 0.2-0.3 (Smirnov et al., 1995, 2002). Although the latter values can appear as rather high if compared to the ones typical of open oceanic areas, a mean AOT of $0.29 \pm 0.22$ is actually found when averaging the 
11 AOT values referring to the Mediterranean Sea and collected by Smirnov et al. (2002) on the basis of 30 years of published data. This average value becomes $0.18 \pm 0.11$ when AOTs $>0.5$ are not considered as possibly "contaminated" by non-maritime aerosols. We have therefore set to 0.3 the upper limit of maritime AOT in our scheme. Due to the variability of both meteorological conditions (relative humidity, mean wind speed) and contamination sources (dust, smoke, urban-industrial aerosols), a significant spread is generally observed in the relative weight of fine and coarse particles in maritime environments. Over the Atlantic and the Pacific Ocean (to which most observations in the literature refer), the fine aerosol contribution to the total AOT is found to reach values up to about $70 \%$ (e.g. Kaufman et al., 2001; Kaufman et al., 2002). In our scheme, we have allowed the fine fraction of maritime aerosol to vary up to 0.8 (see Fig. 1). These assumptions would classify as "maritime aerosol" both dusty conditions with AOT $<0.3$ and continentally-affected conditions with $\mathrm{AOT}<0.3$ and $\mathrm{FF}<0.8$. This choice avoids definition of areas of "uncertain aerosol type" in Fig. 1 and prevents us from over predicting the presence of both continental and/or desert dust particles over the Mediterranean. Being very simple, this scheme is certainly associated to some margin of error (i.e. incorrect aerosol type interpretation), particularly at the border lines of the three regions. In this respect, the outcome of the aerosol mask will be evaluated on the basis of specific cases registered in 2001 in the following section, whereas the overall (statistical) performance of this scheme will be assessed on the basis of the whole 2001 record in Sect. 3.1.

\subsection{Individual tests of the aerosol mask}

Four cases are presented to show the response of the aerosol mask to different aerosol conditions. The latter have been evaluated on the basis of both satellite true-color images (SeaWiFS Mediterranean pictures, as composite of images acquired approximately between 10:00 and 13:00 UT, i.e. almost in coincidence with the MODIS overpass) and wind fields at $700 \mathrm{mb}, 850 \mathrm{mb}$ and $925 \mathrm{mb}$ (images from the NOAA CIRES Climate Diagnostic Center, based on NCEP/NCAR re-analysis, Kalnay et al., 1996). Wind fields are found to be particularly useful in evaluating the transport of continental aerosols. In fact, as opposite to desert dust transport (mostly associated to high AOTs), pollutionrelated plumes are often associated to low aerosol optical thicknesses. In such conditions, the limited aerosol load in the atmospheric column does not allow its identification in the true-color images. This also means that, in these cases, the fine fraction parameter plays a major role in the aerosol type classification.

The first test case, reported in Fig. 2, refers to 26 March 2001, when a dust plume was blown eastward from the Tunisian/Libyan coasts. The SeaWiFS image (Fig. 2a) clearly reveals the geographical extension of the dust plume moving northeast through the Central Mediterranean and reaching up to the Black Sea. The outcome of the aerosol mask applied to this event is shown in Fig. 2b. Here the proposed method appears to reproduce the dust pattern over the Mediterranean. In particular, the southern (cloud-free) edge of the dust plume is well identified (note that in this plot, and in the following case studies, the green border line between the yellow dust plume and the blue maritime aerosol region is falsely produced by the graphical interpolation. In fact, no green border is visible when the dust plume is bounded by black, i.e. unclassified, regions). As opposed to Saharan dust, the mask-derived presence of continental aerosols in Fig. 2b (revealed at the eastern coasts of Spain and over the Gulf of Lion, South France) is not as evident in the SeaWiFS image. An explanation of the aerosol mask outcomes can be derived considering the relevant wind field shown in Fig. 2c. In this plot, the westerly circulation affecting both Spain and Southern France is likely to transport continental aerosols from those regions over the Mediterranean Sea. The wind field in Fig. 2c also confirms the dust advection over the Central/Eastern Mediterranean and further indicates the dust transport to mainly occur at the upper levels. In particular, winds mainly drive dust from Libya to the Eastern Mediterranean at $850 \mathrm{mb}$ (central panel) while strong winds $(\mathrm{v}>16 \mathrm{~m} / \mathrm{s})$ from Algeria and Tunisia also advect dust to the Central Mediterranean at $700 \mathrm{mb}$ (bottom panel).

The second case, reported in Fig. 3, refers to the following day, i.e. 27 March, when some residual dust was still uplifted eastward from the Libyan coasts as revealed by the SeaWiFS image. The corresponding outcome of the aerosol mask reported in Fig. 3b shows that the dust plume from Libya is well detected. Agreement between Fig. 3a and b is also found over the Black Sea and in the Cyprus region, where both the true color SeaWiFS image and the aerosol mask reveal the presence of dust. In this case, wind fields in Fig. 3c indicate the dust transport to mainly occur at upper levels $(\mathrm{P}<850 \mathrm{mb})$, a piece of information that cannot be derived from the true color image of Fig. 3a on its own. Although no evidence of haze is visible in Fig. 3a, the aerosol mask indicates aerosol of anthropogenic origin off the Sardinian coasts in Fig. 3b. Westerly winds flowing over the island (Fig. 3c) are compatible with this result.

The third case, reported in Fig. 4, refers to 1 August 2001. The SeaWiFS picture in Fig. 4a shows two different conditions characterizing the Western and the Eastern Mediterranean, respectively. A well defined dust plume is visible in Fig. 4a, extending from North West Africa northward to Spain and eastward towards Sardinia. Conversely, the Eastern Mediterranean is covered by an inhomogeneous haze layer. The outcome of the relevant aerosol mask is reported in Fig. 4b. Here, the presence of dust is well identified. In particular, the north-eastern edge of the dust plume visible in Fig. 4a is well reproduced in Fig. 4b. In the latter, dust is also detected over the Gulf of Biscay (Northern Spain), a region covered by clouds in Fig. 4a but definitely 

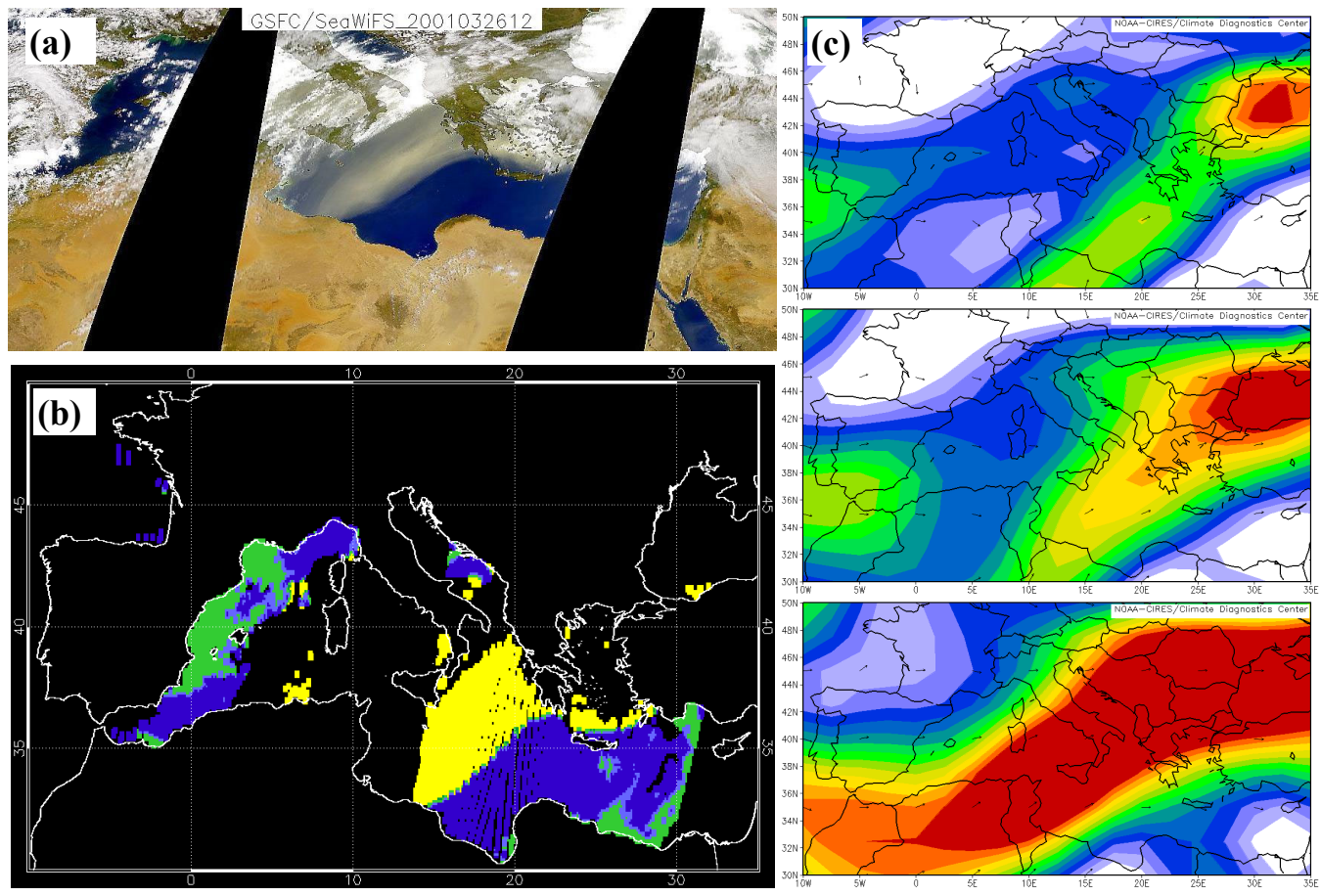

Fig. 2. Conditions over the Mediterranean on 26 March 2001: (a) True color image (from SeaWiFS), (b) corresponding aerosol mask outcome from MODIS FF and AOT data (blue, green and yellow areas corresponding to maritime, continental and desert dust aerosol, respectively), and (c) mean daily composite wind fields at 925, 850 and $700 \mathrm{mb}$ (top, central and bottom panel, respectively; the color bar indicates the wind speed in $\mathrm{m} / \mathrm{s}$; data from NOAA-CIRES based on NCEP/NCAR reanalysis).
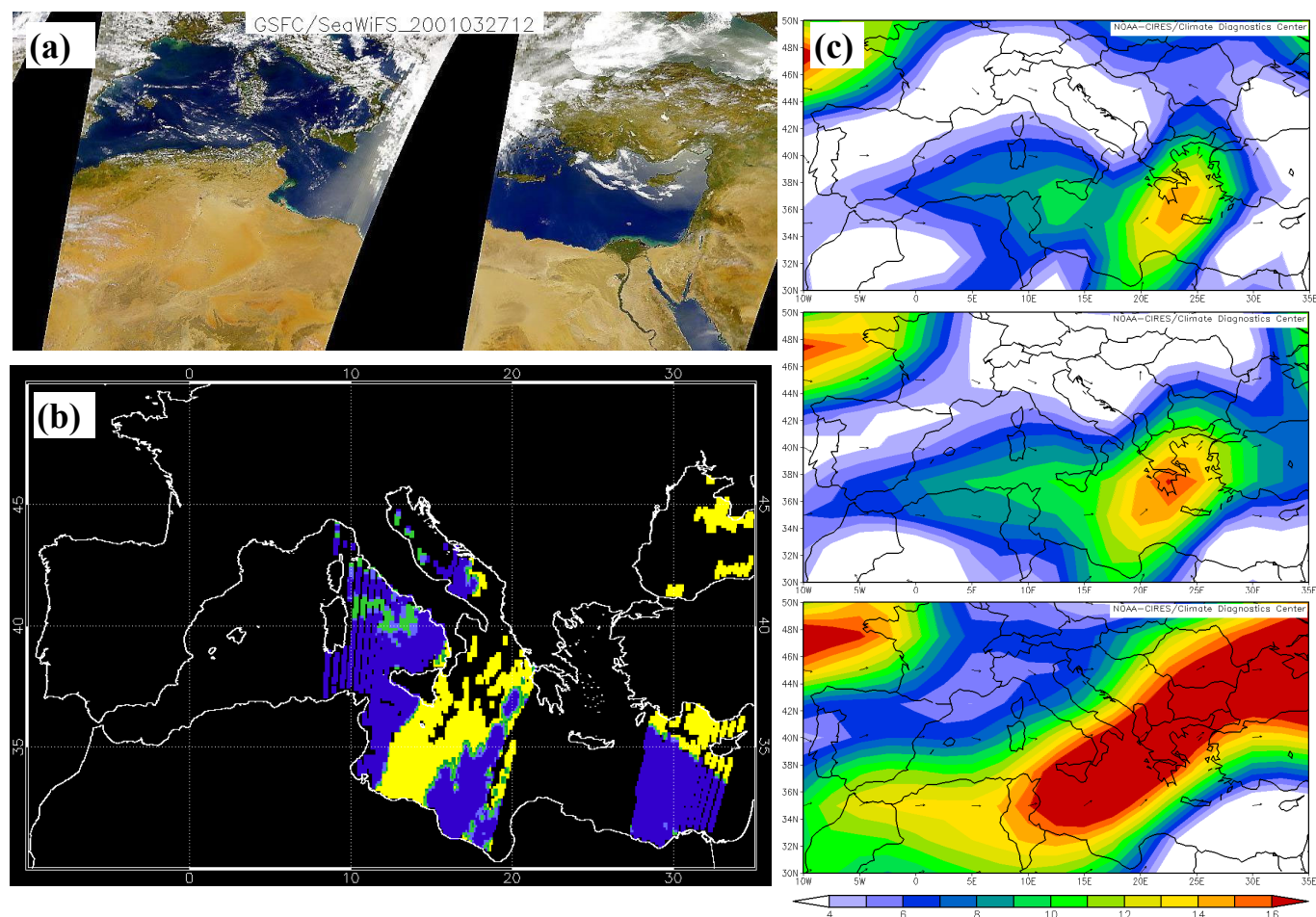

Fig. 3. As in Fig. 2 but case of 27 March 2001. 

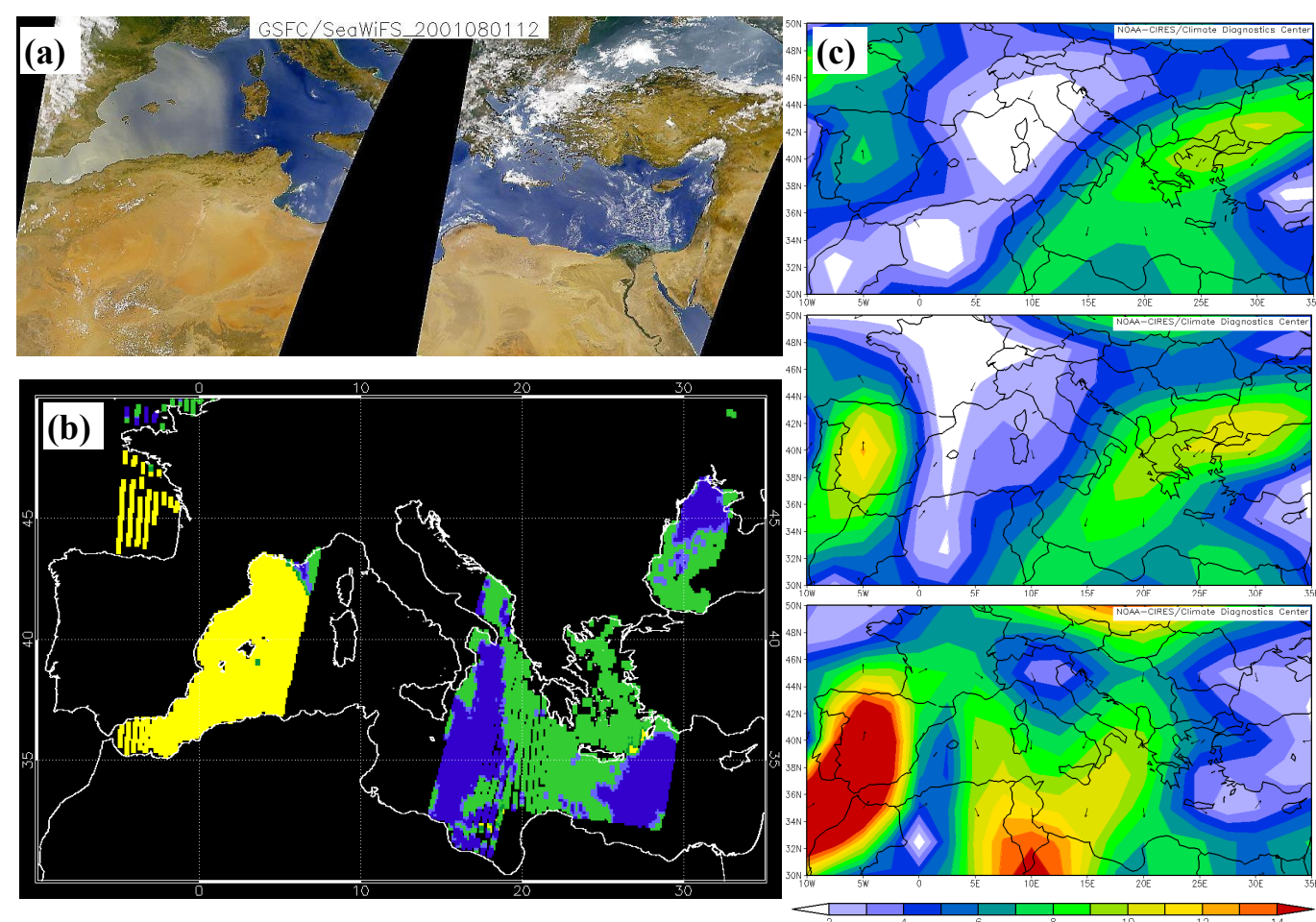

Fig. 4. As in Fig. 2 but case of 1 August 2001.

subject to advection from the North West Saharan regions (i.e. Fig. 4c). In the Eastern Mediterranean the aerosol mask identifies a dominance of continental particles corresponding to the hazy region in Fig. 4a. The origin of such haze is suggested by the wind maps of Fig. 4c. In fact, a North-easterly flow characterizes the Eastern Mediterranean at lower levels $(925,850 \mathrm{mb})$, with the strongest winds $(\mathrm{v} \geq 8 \mathrm{~m} / \mathrm{s})$ in the region within Southern Italy and Crete. This advection pattern is likely to transport over the Mediterranean anthropogenic aerosol from Eastern Europe (Romania, Bulgaria) and Turkey and is therefore consistent with the aerosol mask results of Fig. 4b. As a matter of fact, in August 2001 the Mediterranean Intensive Oxidant Study (MINOS) conducted in Crete (Lelieveld et al., 2002) well highlighted the strong advection of pollutants over the Mediterranean caused by the northerly transport occurring at the lower levels (Sciare, 2003a). It is worth noticing that, in contrast to the pollution advection pattern occurring at the lower levels, the wind field in Fig. 4c indicates dust transport over the Western Mediterranean to mainly occur at the higher levels $(850,700 \mathrm{mb})$.

The fourth case study reported in Fig. 5 refers to 13 October 2001. The SeaWiFS true color image in Fig. 5a reveals a complex atmospheric pattern over the Mediterranean with the presence of both dust and haze, characterizing the western and eastern basin, respectively. In addition, a hazy layer is visible over the Po Valley region (Northern Italy), the Italian east coasts and, partially, over the Adriatic Sea. The corresponding outcome of the aerosol mask derived from
MODIS data is reported in Fig. 5b. This latter clearly depicts the dust plume transported northward from Algeria and well reproduces both the east and west plume edges. Both Eastern Mediterranean and Adriatic Sea haze layers of Fig. 5a are mainly interpreted as continental aerosol in Fig. 5b. However, some minimal misinterpretation of haze as dust is observed. This is mainly produced by the fine fraction being lower than 0.7 in those regions. As mentioned in Sect. 2.1, some percentage of misinterpreted pixels was expected to be associated to the proposed aerosol mask. For this day, wind fields in Fig. 5c suggest advection patterns transporting continental aerosol South-westward to the Mediterranean basin at the lower levels (from Turkey, Bulgaria, Greece) and Saharan dust transported higher up in the atmosphere from the African continent. In this respect, the four cases presented confirm the general particle type-dependent aerosol vertical displacement observed by lidar at a Central Mediterranean site (Gobbi et al., 2004), with desert dust dominating the altitude range $2-6 \mathrm{~km}$ and continental aerosol prevailing in the boundary layers.

Overall, these results indicate that the aerosol mask performs rather well at distinguishing between maritime, continental and desert dust aerosol on the basis of the standard MODIS AOT and FF products. This approach was therefore employed to estimate seasonal contributions of each aerosol type to the total AOT over the Mediterranean. Relevant results are discussed hereafter. 


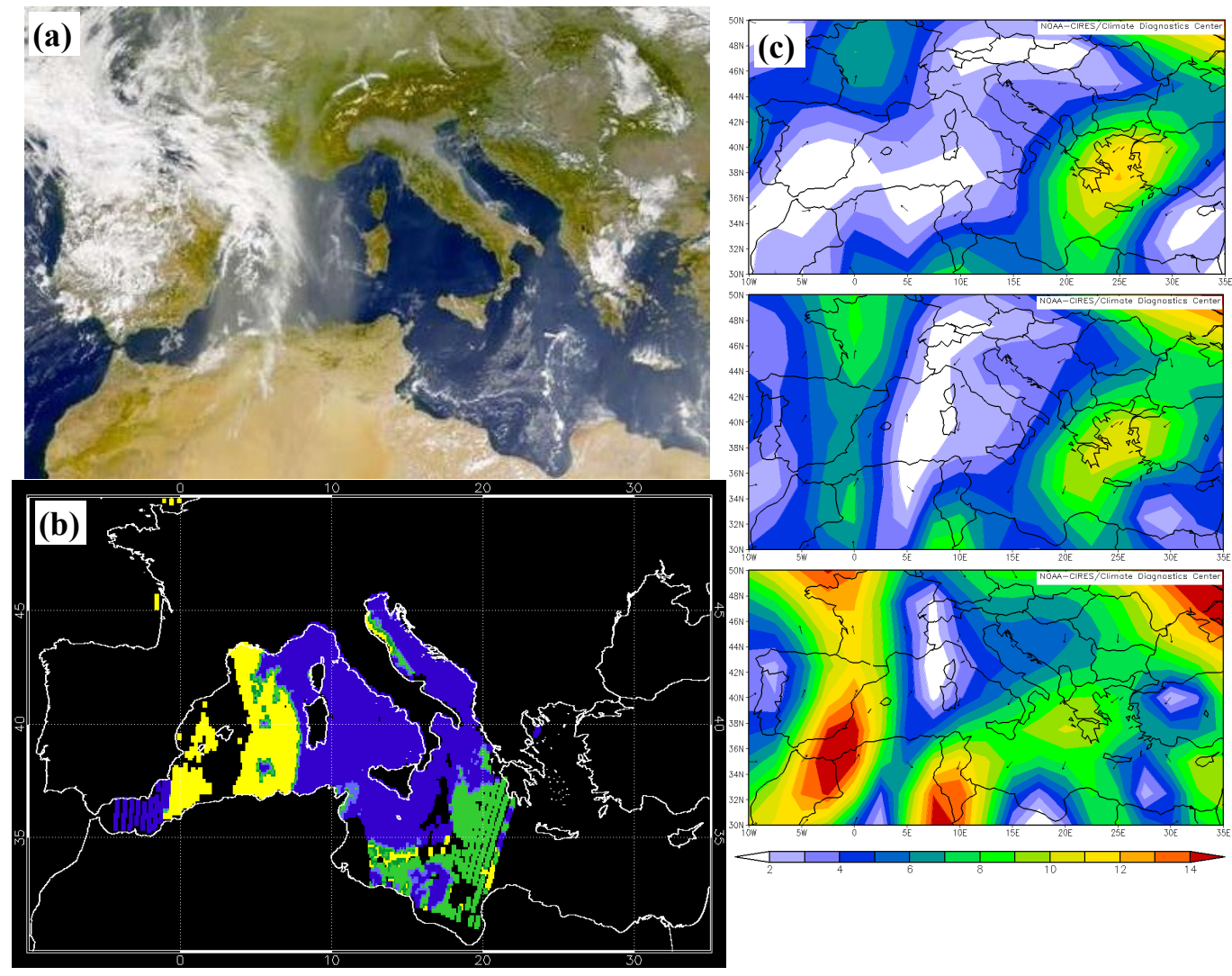

Fig. 5. As in Fig. 2 but case of 13 October 2001.

\section{Results and discussion}

Results of the data analysis are reported in Figs. 6 to 9, referring respectively to the four seasons $D J F, M A M, J J A$ and $S O N$. In each figure, plot a) shows the total mean seasonal aerosol optical thickness $\left(\mathrm{AOT}_{S}\right.$ at $550 \mathrm{~nm}$, given over both land and ocean) whereas plots b), c) and d) show the mean contribution to $\mathrm{AOT}_{S}$ of, respectively, maritime, desert dust and continental aerosol over the basin ( AOT $_{S, \text { type }}^{*}$, the subscript "type" indicating continental ("cont"), maritime ("mar") or desert dust ("dust") aerosols). A detailed definition of the variables $\mathrm{AOT}_{S}$ and $\mathrm{AOT}_{S \text {,type }}^{*}$ is given hereafter. A synopsis of the whole set of aerosol optical thickness variables discussed in this study is provided in Table 1.

For each $0.1^{\circ} \times 0.1^{\circ}$ pixel, the AOT average over the season $S, \mathrm{AOT}_{S}$, is defined as:

$\mathrm{AOT}_{S}=\frac{1}{\mathrm{~N}_{S}} \sum_{j=1}^{\mathrm{N}_{S}} \mathrm{AOT}_{j}$

where $\mathrm{N}_{S}$ is the total number of AOT retrievals $\left(\mathrm{AOT}_{j}\right)$ in the season $S$.

Over the ocean, an aerosol type (continental, maritime or desert dust) is associated to each retrieved $\mathrm{AOT}_{j}$ employing the mask described in Sect. 2.2. Therefore, for each season $S$ (and for each ocean pixel), the mean AOT associated to the three aerosol types is computed as:

$\mathrm{AOT}_{S, \text { type }}=\frac{1}{\mathrm{~N}_{S, \text { type }}} \sum_{j=1}^{\mathrm{N}_{S} \text {,type }} \mathrm{AOT}_{\text {type }, j}$

where $\mathrm{N}_{S \text {,type }}$ is the total number of AOTs classified as "type" (i.e. AOT $\mathrm{Aype}_{j}$ ) in that pixel during the season $S$.

For each ocean pixel, the seasonal frequency of occurrence of each aerosol type, $f_{S, \text { type }}$ is also derived as $f_{S, \text { type }}=\mathrm{N}_{S, \text { type }} / \mathrm{N}_{S}$ (thus resulting $f_{S \text {, cont }}+f_{S \text {, mar }}+f_{S \text {, dust }}=1$ ). This parameter allows one to calculate the mean seasonal contribution of each aerosol type to the total $\mathrm{AOT}_{S}$ as:

$\mathrm{AOT}_{S, \text { type }}{ }^{*}=f_{S, \text { type }} \cdot \mathrm{AOT}_{S \text {,type }}$

Therefore we have, for each pixel, $\mathrm{AOT}_{S}=\mathrm{AOT}_{S \text {, cont }}^{*}+\mathrm{AOT}_{S \text {, mar }}^{*}+\mathrm{AOT}_{S \text {, dust }}^{*}$

In Figs. 6a to 9a, missing data (black areas) are found over bright surfaces (e.g. scarcely vegetated areas or regions covered by snow) where the MODIS retrieval is not performed (Kaufman et al., 1997) or in regions corresponding to a persistent presence of clouds during the whole season. In general, occurrence of cloudy pixels in the investigated region 

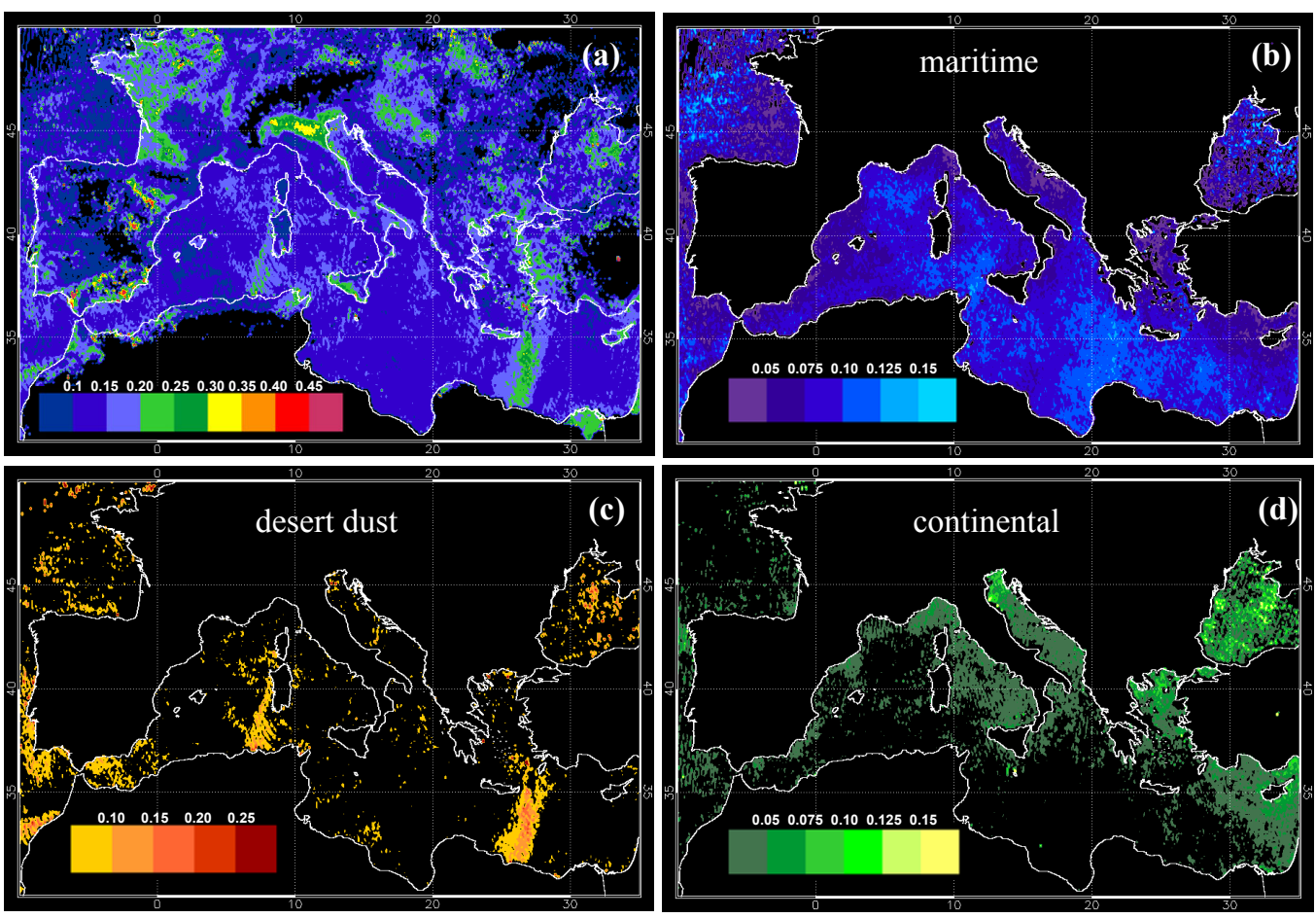

Fig. 6. (a) Winter $(D J F)$ mean seasonal aerosol optical thickness at $550 \mathrm{~nm}$ ( $\mathrm{AOT}_{D J F}$, given over both land and ocean) and mean contribution to $\mathrm{AOT}_{D J F}$ of maritime (b), desert dust (c), and continental (d) aerosol over the basin $\left(\mathrm{AOT}_{D J F, \text { mar }}^{*}\right.$, AOT ${ }_{D J F, \text { dust }}^{*}$ and $\mathrm{AOT}_{D J F, \text { cont }}^{*}$, respectively, with $\mathrm{AOT}_{D J F}=\mathrm{AOT}_{D J F, \text { mar }}^{*}+\mathrm{AOT}_{D J F, \text { dust }}^{*}+\mathrm{AOT}_{D J F \text {, cont }}^{*}$ ). Black regions in plot a) (missing data) correspond to bright surfaces (e.g. sand, snow) or areas with persistent cloud cover during the season.
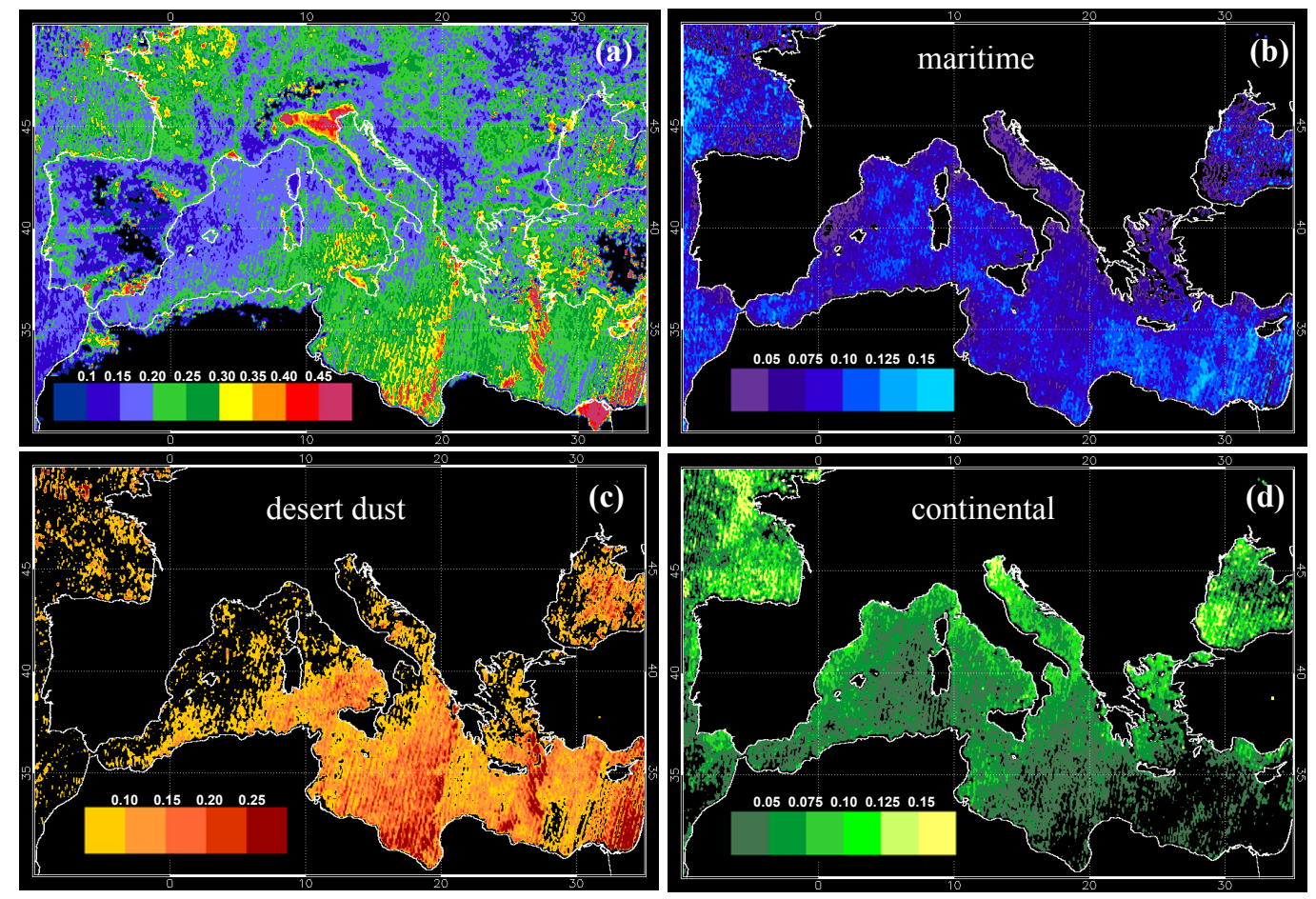

Fig. 7. As in Fig. 6 but for the Spring season (MAM). 

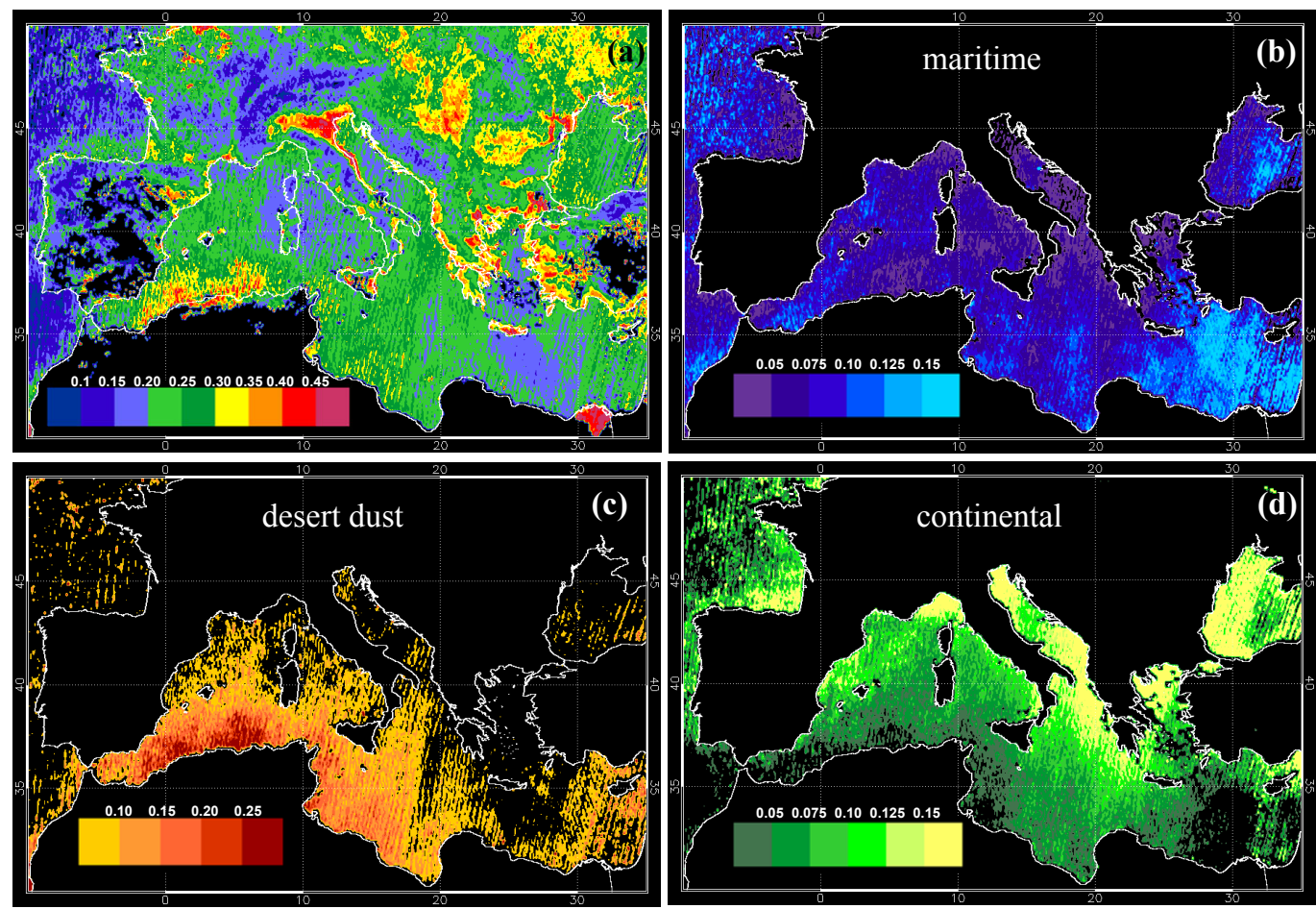

Fig. 8. As in Fig. 6 but for the Summer season (JJA).
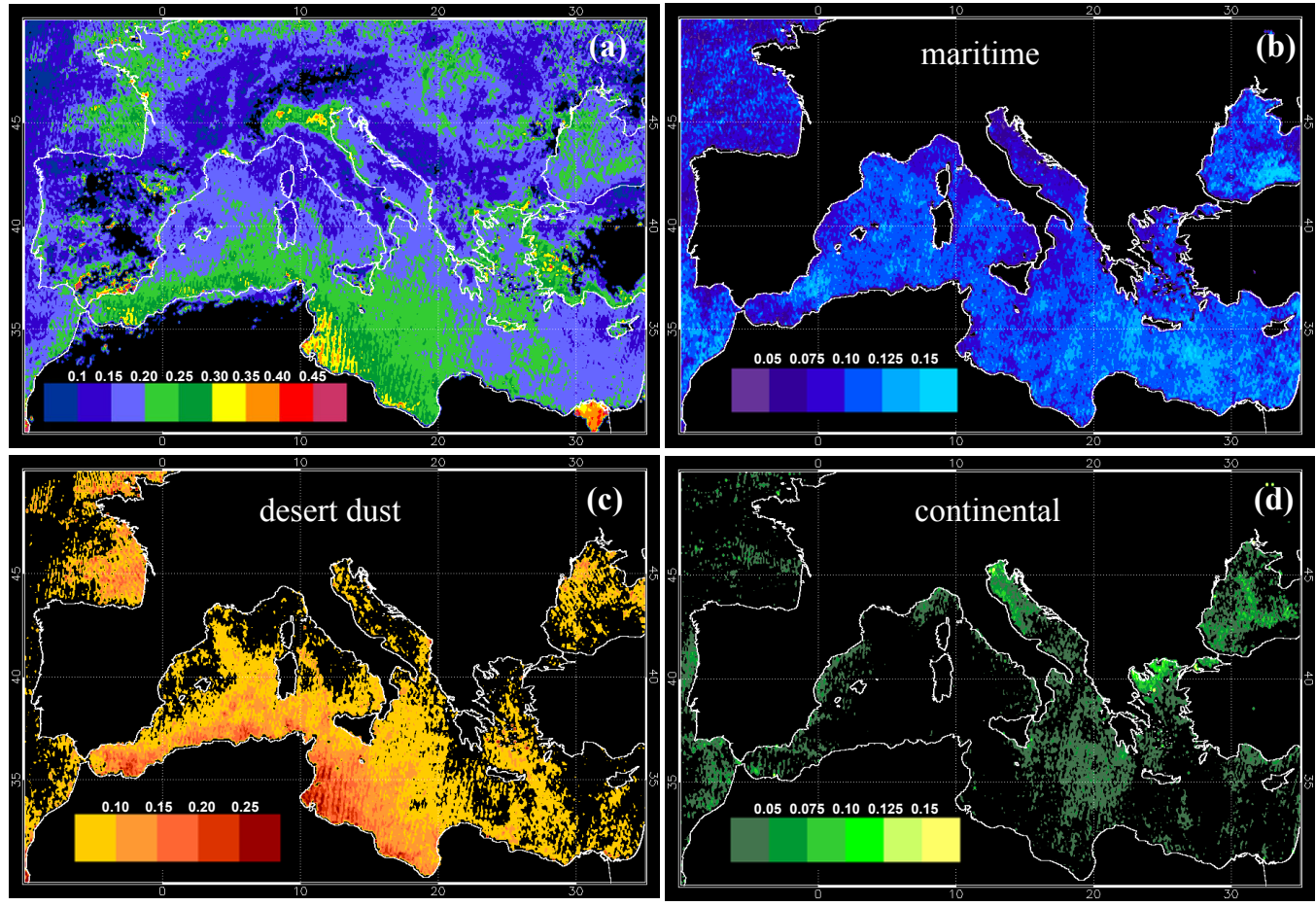

Fig. 9. As in Fig. 6 but for the Fall season $(S O N)$. 
Table 1. Synopsis of the whole set of variables employed to describe the variability of the aerosol optical thickness.

\begin{tabular}{|c|c|c|}
\hline Variable & Definition & Description \\
\hline $\mathrm{AOT}_{S}$ & $\mathrm{AOT}_{S}=\frac{1}{\mathrm{~N}_{S}} \sum_{j=1}^{\mathrm{N}_{S}} \mathrm{AOT}_{j}$ & $\begin{array}{l}\text { Pixel }\left(0.1^{\circ} \times 0.1^{\circ}\right) \text { seasonal average AOT. } \mathrm{N}_{S} \text { is the pixel total } \\
\text { number of } \mathrm{AOT} \text { retrievals }\left(\mathrm{AOT}_{j}\right) \text { in the season } S \text {. }\end{array}$ \\
\hline $\mathrm{AOT}_{S, \text { type }}$ & $\mathrm{AOT}_{S, \text { type }}=\frac{1}{\mathrm{~N}_{S, \text { type }}} \sum_{j=1}^{\mathrm{N}_{S, \text { type }}} \mathrm{AOT}_{\text {type }, j}$ & $\begin{array}{l}\text { Pixel }\left(0.1^{\circ} \times 0.1^{\circ}\right) \text { seasonal average AOT associated to each } \\
\text { aerosol type. } \mathrm{N}_{S} \text {, type is the pixel total number of } \mathrm{AOT}_{j} \\
\left.\text { classified as "type" (i.e, } \mathrm{AOT}_{\mathrm{type}, j}\right) \text { during the season } S \text {. }\end{array}$ \\
\hline $\mathrm{AOT}_{S, \text { type }}^{*}$ & $\mathrm{AOT}_{S, \text { type }}^{*}=f_{S, \text { type }} \cdot \mathrm{AOT}_{S, \text { type }}$ & $\begin{array}{l}\text { Mean seasonal contribution of each aerosol type to the pixel } \\
\text { AOT }_{S} \text {. For each pixel, it is } \mathrm{AOT}_{S}=\mathrm{AOT}_{S, \text { cont }}^{*}+\mathrm{AOT}_{S \text {,mar }}^{*}+ \\
\text { AOT }_{S \text {, dust }} \text { being } f_{S \text {, type }}=\mathrm{N}_{S \text {,type }} / \mathrm{N}_{S} \text { (with } f_{S \text {, cont }}+f_{S \text {, mar }}+f_{S \text {, dust }} \\
=1 \text { ). }\end{array}$ \\
\hline
\end{tabular}

Analysis by Sectors of the Mediterranean basin (e.g. Sect. 3.1)

\begin{tabular}{|c|c|c|}
\hline $\mathrm{AOT}_{S, \mathrm{SEC}}$ & $\mathrm{AOT}_{S, \mathrm{SEC}}=\frac{1}{\mathrm{P}_{\mathrm{SEC}}} \sum_{\mathrm{P}_{k}=1}^{\mathrm{P}_{\mathrm{SEC}}} \mathrm{AOT}_{S, \mathrm{P}_{k}}$ & $\begin{array}{l}\text { Sector (SEC) seasonal }(S) \text { average AOT. } \mathrm{P}_{k} \text { is the } k^{\text {th }} \text { pixel in } \\
\text { sector SEC; } \mathrm{P}_{\mathrm{SEC}} \text { is the total number of pixels in SEC. }\end{array}$ \\
\hline $\mathrm{AOT}_{S, \mathrm{SEC}, \text { type }}$ & $\mathrm{AOT}_{S, \mathrm{SEC}, \text { type }}=\frac{1}{\mathrm{P}_{\mathrm{SEC}}} \sum_{\mathrm{P}_{k}=1}^{\mathrm{P}_{\text {type }, \text { SEC }}} \mathrm{AOT}_{S, \text { type, } \mathrm{P}_{k}}$ & $\begin{array}{l}\text { Sector (SEC) seasonal }(S) \text { average AOT associated to each } \\
\text { aerosol type. } \mathrm{P}_{k} \text { is the } k^{\text {th }} \text { pixel in sector SEC; } \mathrm{P}_{\text {type, SEC }} \text { is the } \\
\text { total number of pixels in SEC in which the parameter } \\
\text { AOT }_{S \text {,type }} \text { is defined; } \mathrm{P}_{\mathrm{SEC}} \text { is the total number of pixels in the } \\
\text { sector SEC (independent from aerosol type). }\end{array}$ \\
\hline $\mathrm{AOT}_{S, \mathrm{SEC}, \text { type }}^{*}$ & $\mathrm{AOT}_{S, \mathrm{SEC}, \text { type }}^{*}=\frac{1}{\mathrm{P}_{\mathrm{SEC}}} \sum_{\mathrm{P}_{k}=1}^{\mathrm{P}_{\text {type, SEC }}} \mathrm{AOT}_{S, \text { type }, \mathrm{P}_{k}}^{*}$ & $\begin{array}{l}\text { Mean seasonal }(S) \text { contribution of each aerosol type to the } \\
\text { sector } \mathrm{AOT}_{S \text {, SEC. }} \mathrm{P}_{k} \text { is the } k^{\text {th }} \text { pixel in SEC; } \mathrm{P}_{\text {type, SEC is the }} \\
\text { total number of pixels in SEC in which the parameter } \\
\mathrm{AOT}_{S \text {,type }}\left(\text { and thus } \mathrm{AOT}_{S \text {,type }} \text { ) is defined; } \mathrm{P}_{\mathrm{SEC}} \text { is the number }\right. \\
\text { of pixels in SEC. For each sector it is } \mathrm{AOT}_{S, \mathrm{SEC}}= \\
\mathrm{AOT}_{S, \mathrm{SEC} \text {,cont }}^{*}+\mathrm{AOT}_{S, \mathrm{SEC} \text {,mar }}^{*}+\mathrm{AOT}_{S, \mathrm{SEC} \text {,dust }}^{*}\end{array}$ \\
\hline $\mathrm{AOT}_{S, \text { type in SEC }}$ & $\mathrm{AOT}_{S, \text { type in SEC }}=\frac{1}{\mathrm{P}_{\text {type, SEC }}} \sum_{\mathrm{P}_{k}=1}^{\mathrm{P}_{\text {type, SEC }}} \mathrm{AOT}_{S, \text { type, } \mathrm{P}_{k}}$ & $\begin{array}{l}\text { Seasonal }(S) \text { average AOT associated to each aerosol type } \\
\text { averaged regionally only over those pixels in sector SEC } \\
\text { where the aerosol type is detected }\left(\mathrm{P}_{\text {type, } \mathrm{SEC}}\right) \text {. Being } \mathrm{P}_{\text {type, } \mathrm{SEC}} \leq \\
\mathrm{P}_{\mathrm{SEC}} \text {, it is } \mathrm{AOT}_{S \text {, type in } \mathrm{SEC}} \neq \mathrm{AOT}_{S, \mathrm{SEC} \text {, type. }}\end{array}$ \\
\hline
\end{tabular}

strongly depends on the season and latitude. During 2001, minimum incidence of clouds (mean cloud fraction $\leq 20 \%$ ) was registered in Summer in the Eastern part of the Mediterranean basin (latitudes $<40^{\circ} \mathrm{N}$, longitudes $>15^{\circ} \mathrm{E}$ ) while maximum incidence of clouds (mean cloud fraction $\geq 70 \%$ ) was registered in Winter above $44^{\circ} \mathrm{N}$. We therefore believe that the seasonal averages presented provide reliable statistics even in the worst cases of highest cloud occurrence (i.e. about $30 \%$ of successful retrievals).

Comparison of the four a)-plots in Figs. 6 to 9 reveals the strong seasonal cycle of the aerosol optical thickness all over the Mediterranean, with the lowest AOT observed in Winter and maximum AOT values registered in SpringSummer. These latter are possibly related to the increase of both photochemical and convective activity registered during the warmest months of the year. For example, in central Italy, the higher AOT values observed in Spring-Summer are associated to aerosol extending up to altitudes of 3-4 km while in the Winter months lower AOT are registered with aerosols confined below $2 \mathrm{~km}$ (Gobbi et al., 2004). The modeling study of Duncan and Bey (2004) also highlights the important role of convection as a pathway to the export of European pollution to the middle troposphere in summer. It is also worth mentioning that surface aerosol mass measurements (PM2.5 and PM10) performed all over Europe (Van Dingenen et al., 2004; Putaud et al., 2004) generally show a different trend with maxima during the cold seasons, particularly at polluted sites. In fact, in the winter months a larger 
condensation of semi-volatile species is expected (Van Dingenen et al., 2004) and, in addition, the low convective activity is likely to keep the aerosol particles in the lowest levels where these are sampled. Conversely, in the warmer months, both reduced $\mathrm{RH}$ at the ground and convection-driven mixing of atmospheric particulate to the higher levels translate into a lower amount of aerosol mass being measured by in situ samplers at the ground. These results confirm that knowledge of the vertical distribution of the particles is necessary to correlate aerosol columnar quantities (as the AOT) to particulate measurements (as PM) at the ground (e.g. Chu et al., 2003; Wang and Christopher, 2003).

Another general feature emerging from Figs. $6 a-9 a$ is the impact of some major European cities and/or industrialized areas. The Po Valley (i.e. the most industrialized region in Italy) is the most evident case of such an effect. An increase in AOT is also evident for example in the Hungarian region and over main urban sites as Marseille in France, Rome and Naples in Italy, and Thessaloniki in Greece. Overall, the AOT pattern observed in plots a) of Figs. 6-9 can be well related to anthropogenic sources as suggested by recent studies performed by Robles Gonzales et al. (2003) and Schaap et al. (2004) by means of chemical-transport models. These studies (in which sea salt and dust aerosol types are not considered) show the AOT field over Europe to be strongly related to the distribution of inorganic aerosol precursor emissions (sulfates, nitrates). For example, the Po Valley and the Eastern Europe region (e.g. Hungary, Bulgaria) are shown to be characterized by higher concentrations of $\mathrm{NO}_{3}$ and/or $\mathrm{SO}_{4}$ and $\mathrm{SO}_{2}$ with respect to Western Europe, where high values of these constituents are only found in the northern coast of Spain. In Figs. 6a-9a, the high AOT values over the Nile-delta region are likely affected by water contamination.

The winter plots of Fig. 6 show the AOT in the Mediterranean region to be mostly confined below $0.15-0.20$, with higher values over land only registered in Northern Italy, Western France and in the Hungarian region. AOT values higher that 0.15 over the Mediterranean Sea are mainly related to some Saharan dust transport events as revealed by Fig. 6c. However, minimum incidence of long range dust transport is registered in this season, in agreement with the seasonal analysis by Gobbi et al. (2004) performed employing lidar data collected at Rome in the year 2001. Figure $6 \mathrm{~d}$ reveals some advection of continental aerosol over the Mediterranean with larger impact in the North and NorthEastern regions. This pattern is compatible with the dominance of Westerlies over the Mediterranean in Winter (e.g. Stohl et al., 2002).

Opposite to the winter case, the Spring plots of Fig. 7 show a mean Mediterranean AOT generally higher than 0.15 over both land and ocean. In the Po Valley region AOT reaches values higher than 0.45 , almost double with respect to Winter. Figures $7 \mathrm{c}$ and $\mathrm{d}$ reveal that both dust and continental aerosols contribute to the high AOT values observed over the Mediterranean and the Black Sea. In particular, a major im- pact of Saharan dust is evident over the Eastern and the Central Mediterranean, while advection of continental aerosol mainly affects Western and Central Mediterranean as well as the North Atlantic (Bay of Biscay) and the Black Sea. It is worth mentioning that, by exploiting the polarization capabilities of the POLDER instrument, Tanré et al. (2001) highlighted a maximum impact of pollution events over central Europe in Spring. However, in that study July and August data were not available. Comparison of Figs. $7 \mathrm{a}$ and $\mathrm{c}$ shows the contribution of dust to the total AOT to reach $60 \%$ close to the Libyan and Egyptian-Israeli coasts. A similar contribution by continental aerosol is found to the North of Spain, in the Black Sea and in the Northern Adriatic Sea (right in the outflow of the Po Valley region).

As already pointed out, maximum aerosol optical thickness values are reached in Summer (Fig. 8), with AOT $>0.2$ prevailing over both the European continent and the Mediterranean basin. Actually, the summer AOT field of Fig. 8a compares quite well with the one retrieved at $555 \mathrm{~nm}$ by Robles Gonzales et al. (2003) employing August 1997 data collected by the ATSR-2 radiometer on board the ESA ERS-2 platform. Overall, model calculations performed over Europe for the summer period (August) by Robles Gonzales et al. (2003) suggest a maximum contribution of nitrates and sulphates to the total AOT (at $555 \mathrm{~nm}$ ) of $10 \%$ and $70 \%$, respectively. Figure $8 \mathrm{a}$ shows a particular AOT increase with respect to Spring over Eastern Europe (AOT $>0.3$ over Hungaria, Romania, Ukraine). This effect is possibly connected to the frequent biomass burning events that occurred in Eastern Europe in the Summer 2001 (e.g. Salisbury et al., 2003; Sciare et al., 2003b). It is worth mentioning that, although not specifically addressed in this study, biomass burning episodes are likely to be classified as continental aerosol in our scheme. In fact, these are characterized by high AOT associated to a large fraction of fine particles (e.g. Dubovik et al., 2002). In Fig. 8a, high AOT values are observed in Crete and in the Southeastern European coastal regions (mainly Greece and Turkey). Some water contamination in land pixels and water color impact on the ocean pixels are likely responsible for this effect. It is however worth mentioning that the observed MODIS AOT as high as $0.4( \pm 0.13)$ in Crete and along the Turkish coasts are still compatible with the AERONET data (http://aeronet.gsfc.nasa.gov). In fact, the AERONET quality assured AOT values available for those areas in this period of the year show a mean AOT $=0.23 \pm 0.08$ in the FORTH-Crete site $\left(35.3^{\circ} \mathrm{N}, 25.7^{\circ} \mathrm{E}\right.$, Crete, Greece, August 2003) and a mean AOT $=0.44 \pm 0.24$ in the IMSMETU-Erdemli coastal site $\left(36.6^{\circ} \mathrm{N}, 34.2^{\circ} \mathrm{E}\right.$, Turkey, August 2000). Figure 8d shows the Summer impact of continental aerosol (maximum of the year) to extend all over the basin, with particular strength over the Central and Eastern Mediterranean (with the exception of the area South of Cyprus). These results are in agreement with the recent analysis of the Angstrom exponent variability over the Mediterranean obtained by Jamet et al. (2004) from neural network 
inversion of SeaWiFS data for the year 2000. Overall, the AOT pattern in Fig. 8d suggests a prevalent northerly flow in the lower layers, where transport of pollutants mainly occurs (e.g. Stohl et al., 2002). In this respect, an extensive analysis of air mass trajectories in the Mediterranean during the MINOS campaign (August 2001) presented by Lelieveld et al. (2002), revealed a dominant northerly flow below $4 \mathrm{~km}$, confirming the results by Stohl et al. (2002) and Duncan and Bey (2004) of a Summer southward flow of European pollution over the Mediterranean basin and Africa. Conversely, in the middle and upper troposphere (i.e. in the region where the Saharan dust transport mainly occurs), Lelieveld et al. (2002) found westerly/southerly winds to prevail. In fact, similarly to the Spring case (Fig. 7), the Summer continental aerosol distribution in the Mediterranean basin appears to complement the Saharan dust one (Figs. $8 \mathrm{c}$ and d). In particular, continental aerosol dominate the Central and Eastern basin whereas a major impact of dust is observed in the CentralWestern Mediterranean. With respect to the Spring conditions, a Summer westward shift of Saharan dust transport is thus observed in 2001. This is in agreement with the general pattern of dust transport over the Mediterranean emerging from multi annual analysis of satellite data (Moulin et al., 1998; Israelevich et al., 2002). It is also worth noticing that the minor impact of both continental and dust aerosol over the South-eastern Mediterranean (south of Cyprus) reveals the large maritime contribution to the AOT in this region (Fig. 8b). A Summer increase in biogenic (marine phytoplankton) sulphate aerosols could account for such result. In fact, an important impact of biogenic sulphur is found in the Summer Eastern Mediterranean atmosphere, even though the major source of sulphate in this region is still assigned to long-range transport (Ganor et al., 2000; Kouvarakis et al., 2002).

Figure 9 shows the substantial reduction of the Fall AOT average with respect to the Summer one. However, AOT values as high as 0.2 are still observed over a large part of the European continent (e.g. Western France, Northern Italy, Hungarian region) as well as over Southern Mediterranean. In this latter region AOT values are affected by Saharan dust whose contribution to the total AOT is still of the order of $50 \%$, and even larger close to the African coasts (Fig. 9c). While a minimum impact of Saharan dust is observed in winter (Fig. 6c), the minimum impact of continental aerosol is registered in Fall (Fig. 9d), with residual continental influences mainly visible in the Northern Adriatic Sea (outflow of the Po Valley region) and in the Greek Halkidiki peninsula. In this respect, it is worth mentioning a further factor playing a major role in determining the observed aerosols seasonal pattern: precipitation, i.e. the most efficient removal process of atmospheric particulate. In fact, the observed seasonal pattern of the Mediterranean AOT should also be interpreted in connection to the seasonal and latitudinal pattern of precipitation in the Mediterranean (e.g. Mariotti et al., 2002). In particular, even considering the mentioned increase of pho- tochemical and convective activity in Spring-Summer, the higher mean AOT registered in this period of the year is also a consequence of a minimum aerosol scavenging by precipitation. Conversely, the higher precipitation rate registered over the Mediterranean in Fall and Winter (particularly at latitudes $\geq 40^{\circ} \mathrm{N}$ ) tends to reduce the mean residence time of aerosols in the atmosphere, and, in turn, the mean AOT. In the case of non-local aerosol (e.g. continental aerosol transported over the Mediterranean), this precipitation effect is expected to be even more evident. In fact, when aerosols travel time is comparable to the mean time interval between two rain events, the advection-related aerosol load cannot be completely re-established (e.g. Bergametti et al., 1989). Interestingly, during the year 2001 the highest seasonal rain rates $\left(\mathrm{R}_{r}\right)$ over the Mediterranean basin were registered in Fall $\left(\mathrm{R}_{r}\right.$ mean values higher than $2 \mathrm{~mm} /$ day) with maximum values $\left(\mathrm{R}_{r}>3 \mathrm{~mm} /\right.$ day $)$ over the Adriatic Sea, the Balearic Islands and the Cyprus region. In Winter the mean $\mathrm{R}_{r}$ over the basin was $1.5-2.5 \mathrm{~mm} /$ day whereas the Spring and Summer means were $\mathrm{R}_{r}<1$ and $\mathrm{R}_{r}<0.5 \mathrm{~mm} /$ day, respectively (data from NCEP/NCAR reanalysis).

\subsection{Mediterranean AOT data summary}

To provide a summary of the seasonal and regional variability discussed so far, aerosol optical thicknesses averaged over both season and Mediterranean sectors were computed and are reported in Table 2. Regional averages have been performed considering the Mediterranean basin as divided into the ten sectors (SEC) shown in Fig. 10. These were selected to define a Western, Central and Eastern Mediterranean basin (longitudinal partitions at $8^{\circ}$ and $21^{\circ} \mathrm{W}$ ) and to facilitate the evaluation of North-to-South AOT gradients (latitudinal partitions at $35^{\circ}, 38^{\circ}$ and $41^{\circ} \mathrm{N}$ ). A detailed definition of the variables reported in Table 2 is given hereafter. Tables 2a, $\mathrm{b}, \mathrm{c}$, and d refer to the Winter, Spring, Summer and Fall averages, respectively. The seasonal averages $\mathrm{AOT}_{S \text {,type }}$ and AOT $_{S \text {,type }}^{*}$ (see Figs. 6-9b, c, d) defined in Table 1 and derived for each ocean pixel, were averaged regionally. This is, for the ten sectors of Fig. 10 the following quantities were computed:

$$
\begin{aligned}
& \operatorname{AOT}_{S, \text { SEC ,type }}=\frac{1}{\mathrm{P}_{\mathrm{SEC}}} \sum_{\mathrm{P}_{\mathrm{k}}=1}^{\mathrm{P}_{\text {type,SEC }}} \mathrm{AOT}_{S, \text { type, } \mathrm{P}_{\mathrm{k}}} \\
& \operatorname{AOT}_{S, \text { SEC }, \text { type }} *=\frac{1}{\mathrm{P}_{\mathrm{SEC}}} \sum_{\mathrm{P}_{\mathrm{k}}=1}^{\mathrm{P}_{\mathrm{type}, \mathrm{SEC}}} \mathrm{AOT}_{S, \text { type, } \mathrm{P}_{\mathrm{k}}}{ }^{*}
\end{aligned}
$$

where the subscript $\mathrm{P}_{k}$ indicates the $k$-th pixel in sector SEC; $\mathrm{P}_{\text {type,SEC }}$ is the total number of pixels in SEC in which the

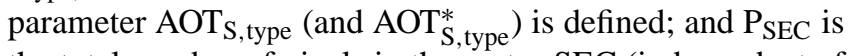
the total number of pixels in the sector SEC (independent of the aerosol type).

It is worth noticing that, since an aerosol type is not necessarily detected in the whole sector during a season (i.e. being 


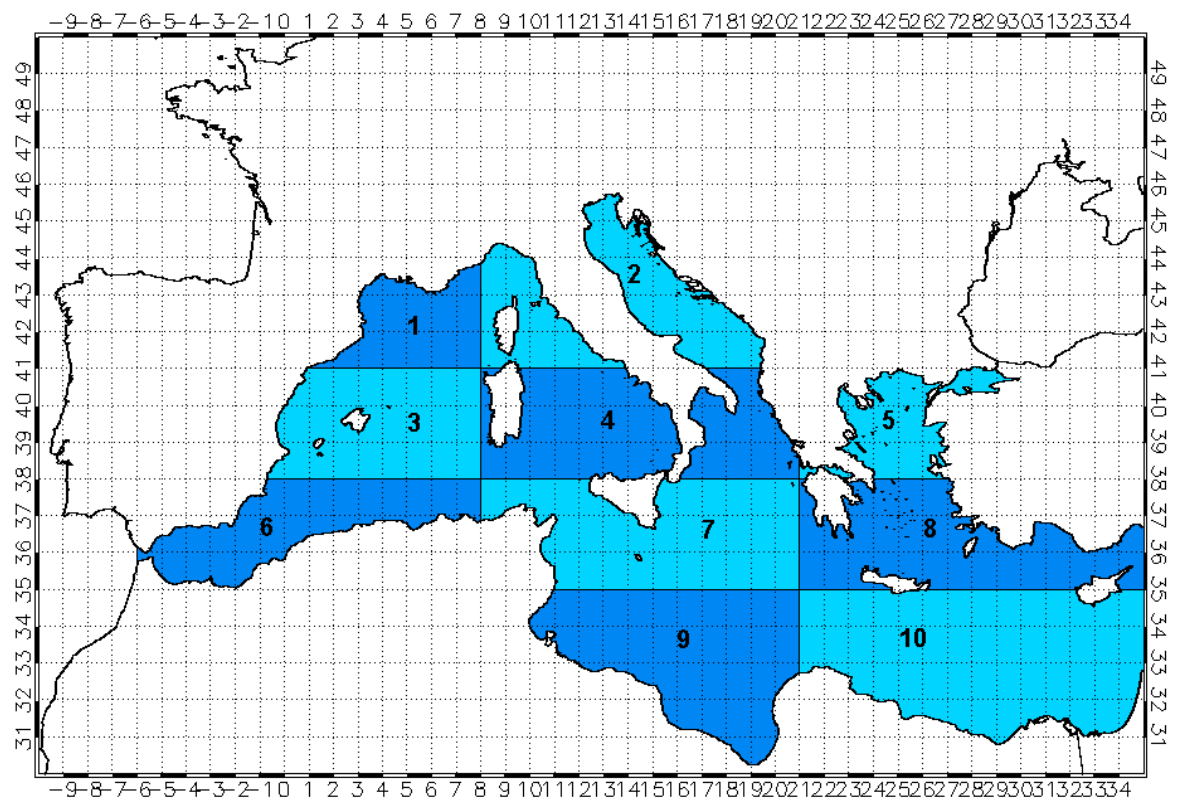

Fig. 10. The ten sectors of the Mediterranean basin employed in the analysis. The relative area of each sector (in percent) is $4.7,8.1,9.2$, $11.3,3.1,7.8,12.6,10.2,13.4,19.6$, respectively.

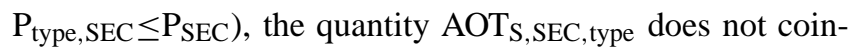
cide with $\mathrm{AOT}_{\mathrm{S}}$, type in SEC, i.e. the AOT averaged only over the pixels classified as "type" in sector SEC

$$
\begin{aligned}
& \text { (it is : } \mathrm{AOT}_{S, \mathrm{SEC}, \text { type }}=\frac{1}{\mathrm{P}_{\mathrm{SEC}}} \sum_{\mathrm{P}_{\mathrm{k}}=1}^{\mathrm{P}_{\text {type, } \mathrm{SEC}}} \mathrm{AOT}_{S, \text { type }, \mathrm{P}_{\mathrm{k}}} \leq \\
& \leq \frac{1}{\mathrm{P}_{\text {type }, \mathrm{SEC}}} \sum_{\mathrm{P}_{\mathrm{k}}=1}^{\mathrm{P}_{\text {type, SEC }}} \mathrm{AOT}_{S, \text { type }, \mathrm{P}_{\mathrm{k}}}=\mathrm{AOT}_{S, \text { type in SEC }} \text { ). }
\end{aligned}
$$

For example: the quantity $\mathrm{AOT}_{D J F, 5 \text {,dust in Table } 2 \mathrm{a}}$ is the desert dust average AOT over the whole sector 5 in winter $(0.18 \pm 0.07)$. However, since only a fraction of sector 5 was covered by dust, $\mathrm{AOT}_{D J F, 5 \text {, dust is smaller }}$ than the mean AOT of dust events in that sector, i.e. $\mathrm{AOT}_{D J F \text {, dust in } 5}(0.44 \pm 0.11)$. For completeness, the whole

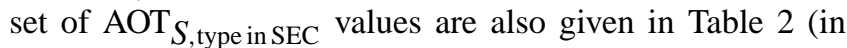
parentheses).

Data presented in Table 2 clearly show the following:

1. A seasonal pattern of the aerosol optical thickness in the Mediterranean, with mean AOT values $\left(\mathrm{AOT}_{\mathrm{S}, \mathrm{SEC}}\right.$ ) spanning the range $0.12-0.14$ in Winter, $0.17-0.28$ in Spring, 0.20-0.28 in Summer and 0.15-0.26 in Fall.

2. A seasonal cycle of dust distribution within the basin, associated to a South-to-North gradient. In fact, a Spring maximum dust impact is found in the EasternCentral Mediterranean (AOT A $_{A M, \text { SEC, dust }}>0.45$, with dust percentage AOT contribution $>40 \%$ in Sectors 10-8 and 9-7-4, respectively). In Summer and Fall dust maxima shift to the Central-Western Mediterranean

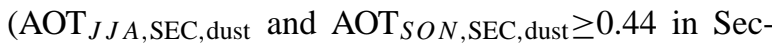
tors 9-7-4, and 6-3, with dust percentage contributions to $\mathrm{AOT} \geq 28 \%$ ). In Winter a residual dust activity is registered in the Western part of the basin (AOT $_{D J F, S E C, \text { dust }} \geq 0.32$ in sectors 6-3-1) but in the South-Eastern Mediterranean the beginning of a "new cycle" is also detected $\left(\mathrm{AOT}_{D J F, \mathrm{SEC} \text {, dust }}=0.37\right.$ in Sector 10).

3. A transport of continental aerosol from the European continent over the basin with maximum impact along the coastal regions. In fact, the highest contribution of continental particles to the total AOT is found in Sectors 2 and 5 in Winter $(>30 \%)$, in Sectors 1, 2, 5 in Spring $(\geq 35 \%)$, in Sectors $1,2,4,5,8$ in Summer $(\geq 43 \%)$ and again in Sectors 2 and 5 in Fall $(\geq 19 \%)$.

A graphical representation of these patterns in terms of aerosol mass is provided in the following Sect. 3.2.

In the case of desert dust, the results obtained for the year 2001 and reported in Table 2 can be compared to the 11year climatology (from 1984 to 1994) obtained by Moulin et al. (1998). In that study, seasonal averages of the optical thickness due to Saharan dust over the Western, Central and Eastern Mediterranean were computed on the basis of daily analysis of Meteosat images. To be compared to the Moulin et al. (1998) data, the dust contribution to the total AOT in the Western $(\mathrm{SEC}=1,3,6)$, Central $(\mathrm{SEC}=2,4,7,9)$ and Eastern $(\mathrm{SEC}=5,8,10)$ Mediterranean can be computed by averaging the $\mathrm{AOT}_{S \text {,SEC,dust }}^{*}$ values in Table 2 over the relevant 
Table 2a. Winter $\mathrm{AOT}_{S, \mathrm{SEC} \text {,type }}$ and $\mathrm{AOT}_{S, \mathrm{SEC} \text {,type }}^{*}$ averages $(S=D J F)$ and relevant standard deviations (s.d.) computed for the

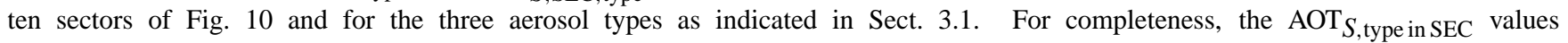

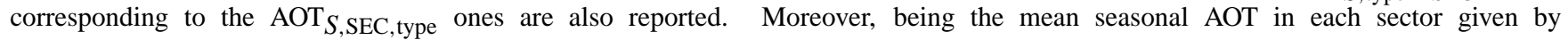
$\mathrm{AOT}_{\mathrm{S}, \mathrm{SEC}}=\mathrm{AOT}_{S, \mathrm{SEC} \text {, cont }}^{*}+\mathrm{AOT}_{S, \mathrm{SEC} \text {, mar }}^{*}+\mathrm{AOT}_{S, \mathrm{SEC} \text {, dust }}^{*}$, the values $\mathrm{AOT}_{S, \mathrm{SEC}, \text { type }}^{*}$ AOT $_{S, \mathrm{SEC}}$ (in percent) are also reported in the Table, indicating the relative contribution of each aerosol type to the seasonal AOT in the sector.

\begin{tabular}{|c|c|c|c|c|c|c|c|}
\hline \multirow[t]{2}{*}{ Sector } & \multicolumn{3}{|c|}{$\begin{array}{l}\operatorname{AOT}_{D J F, \text { SEC }, \text { type }} \pm \text { s. d. } \\
\left(\text { AOT }_{D J F, \text { type in SEC }} \pm \text { s. d.) }\right.\end{array}$} & \multicolumn{3}{|c|}{$\begin{array}{c}\operatorname{AOT}_{D J F, \text { SEC, type }}^{*} \pm \text { s. d. } \\
\left(\mathrm{AOT}_{D J F, \text { SEC, type }}^{*} / \mathrm{AOT}_{D J F, \text { SEC }}\right) \text { in \% }\end{array}$} & \multirow[t]{2}{*}{$\begin{array}{c}\operatorname{AOT}_{D J F, \text { SEC }} \\
\pm \text { s. d. }\end{array}$} \\
\hline & dust & continental & maritime & dust & continental & maritime & \\
\hline 1 & $\begin{array}{c}0.32 \pm 0.09 \\
(0.41 \pm 0.10)\end{array}$ & $\begin{array}{c}0.13 \pm 0.05 \\
(0.13 \pm 0.06)\end{array}$ & $\begin{array}{c}0.12 \pm 0.02 \\
(0.12 \pm 0.02)\end{array}$ & $\begin{array}{c}0.03 \pm 0.01 \\
(22 \%)\end{array}$ & $\begin{array}{c}0.02 \pm 0.01 \\
(14 \%)\end{array}$ & $\begin{array}{c}0.09 \pm 0.02 \\
(64 \%)\end{array}$ & $0.14 \pm 0.02$ \\
\hline 2 & $\begin{array}{c}0.27 \pm 0.14 \\
(0.45 \pm 0.18)\end{array}$ & $\begin{array}{c}0.14 \pm 0.06 \\
(0.15 \pm 0.06)\end{array}$ & $\begin{array}{c}0.11 \pm 0.02 \\
(0.11 \pm 0.02)\end{array}$ & $\begin{array}{c}0.02 \pm 0.02 \\
(15 \%)\end{array}$ & $\begin{array}{c}0.04 \pm 0.02 \\
(31 \%)\end{array}$ & $\begin{array}{c}0.07 \pm 0.02 \\
(54 \%)\end{array}$ & $0.13 \pm 0.04$ \\
\hline 3 & $\begin{array}{c}0.32 \pm 0.21 \\
(0.50 \pm 0.26)\end{array}$ & $\begin{array}{c}0.11 \pm 0.08 \\
(0.11 \pm 0.08)\end{array}$ & $\begin{array}{c}0.11 \pm 0.02 \\
(0.11 \pm 0.02)\end{array}$ & $\begin{array}{c}0.02 \pm 0.02 \\
(17 \%)\end{array}$ & $\begin{array}{c}0.02 \pm 0.01 \\
(17 \%)\end{array}$ & $\begin{array}{c}0.08 \pm 0.02 \\
(66 \%)\end{array}$ & $0.12 \pm 0.03$ \\
\hline 4 & $\begin{array}{c}0.30 \pm 0.15 \\
(0.47 \pm 0.19)\end{array}$ & $\begin{array}{c}0.14 \pm 0.06 \\
(0.15 \pm 0.06)\end{array}$ & $\begin{array}{c}0.12 \pm 0.02 \\
(0.12 \pm 0.02)\end{array}$ & $\begin{array}{c}0.02 \pm 0.02 \\
(14 \%)\end{array}$ & $\begin{array}{c}0.03 \pm 0.01 \\
(22 \%)\end{array}$ & $\begin{array}{c}0.09 \pm 0.02 \\
(64 \%)\end{array}$ & $0.14 \pm 0.02$ \\
\hline 5 & $\begin{array}{c}0.18 \pm 0.07 \\
(0.44 \pm 0.11)\end{array}$ & $\begin{array}{c}0.13 \pm 0.05 \\
(0.14 \pm 0.06)\end{array}$ & $\begin{array}{c}0.11 \pm 0.04 \\
(0.12 \pm 0.04)\end{array}$ & $\begin{array}{c}0.02 \pm 0.03 \\
(16 \%)\end{array}$ & $\begin{array}{c}0.05 \pm 0.03 \\
(42 \%)\end{array}$ & $\begin{array}{c}0.05 \pm 0.03 \\
(42 \%)\end{array}$ & $0.12 \pm 0.05$ \\
\hline 6 & $\begin{array}{c}0.43 \pm 0.25 \\
(0.58 \pm 0.29)\end{array}$ & $\begin{array}{c}0.08 \pm 0.05 \\
(0.08 \pm 0.05)\end{array}$ & $\begin{array}{c}0.11 \pm 0.02 \\
(0.11 \pm 0.02)\end{array}$ & $\begin{array}{c}0.03 \pm 0.03 \\
(25 \%)\end{array}$ & $\begin{array}{c}0.02 \pm 0.01 \\
(17 \%)\end{array}$ & $\begin{array}{c}0.07 \pm 0.02 \\
(58 \%)\end{array}$ & $0.12 \pm 0.04$ \\
\hline 7 & $\begin{array}{c}0.30 \pm 0.12 \\
(0.44 \pm 0.15)\end{array}$ & $\begin{array}{c}0.14 \pm 0.08 \\
(0.14 \pm 0.08)\end{array}$ & $\begin{array}{c}0.12 \pm 0.02 \\
(0.12 \pm 0.02)\end{array}$ & $\begin{array}{c}0.02 \pm 0.02 \\
(14 \%)\end{array}$ & $\begin{array}{c}0.02 \pm 0.02 \\
(14 \%)\end{array}$ & $\begin{array}{c}0.10 \pm 0.02 \\
(72 \%)\end{array}$ & $0.14 \pm 0.02$ \\
\hline 8 & $\begin{array}{c}0.23 \pm 0.18 \\
(0.53 \pm 0.26)\end{array}$ & $\begin{array}{c}0.10 \pm 0.04 \\
(0.11 \pm 0.04)\end{array}$ & $\begin{array}{c}0.12 \pm 0.02 \\
(0.12 \pm 0.02)\end{array}$ & $\begin{array}{c}0.02 \pm 0.04 \\
(17 \%)\end{array}$ & $\begin{array}{c}0.03 \pm 0.02 \\
(25 \%)\end{array}$ & $\begin{array}{c}0.07 \pm 0.03 \\
(58 \%)\end{array}$ & $0.12 \pm 0.05$ \\
\hline 9 & $\begin{array}{c}0.31 \pm 0.10 \\
(0.42 \pm 0.12)\end{array}$ & $\begin{array}{c}0.08 \pm 0.07 \\
(0.10 \pm 0.08)\end{array}$ & $\begin{array}{c}0.11 \pm 0.01 \\
(0.11 \pm 0.01)\end{array}$ & $\begin{array}{c}0.02 \pm 0.01 \\
(15 \%)\end{array}$ & $\begin{array}{c}0.01 \pm 0.01 \\
(8 \%)\end{array}$ & $\begin{array}{c}0.10 \pm 0.01 \\
(77 \%)\end{array}$ & $0.13 \pm 0.02$ \\
\hline 10 & $\begin{array}{c}0.37 \pm 0.28 \\
(0.59 \pm 0.36)\end{array}$ & $\begin{array}{c}0.10 \pm 0.04 \\
(0.10 \pm 0.04)\end{array}$ & $\begin{array}{c}0.13 \pm 0.02 \\
(0.13 \pm 0.02)\end{array}$ & $\begin{array}{c}0.03 \pm 0.03 \\
(22 \%)\end{array}$ & $\begin{array}{c}0.02 \pm 0.02 \\
(14 \%)\end{array}$ & $\begin{array}{c}0.09 \pm 0.02 \\
(64 \%)\end{array}$ & $0.14 \pm 0.04$ \\
\hline
\end{tabular}

sectors, weighted by the area of each sector (see Fig. 10 caption). In this way, we find that 8 out of our 12 seasonal averages (four seasons times the three regions) are within the variability ranges obtained by Moulin et al. (1998), whereas the variability ranges of 11 out of our 12 seasonal averages overlap with the ones of Moulin et al. (1998). Our mean dust optical thickness is however generally lower (about $-30 \%$ ), with maximum and minimum relative differences registered in Winter $(-50 \%)$ and Fall $(-7 \%)$, respectively.

The sector analysis described above was also used as a control tool of the criteria adopted to built the aerosol mask. To this purpose, the mean seasonal AOT values characterizing each aerosol type in the different sectors

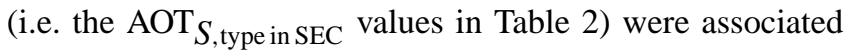
to the corresponding mean seasonal fine fraction values, $\mathrm{FF}_{S \text {,type in SEC }}$. Relevant results are shown in Fig. 11, where the three regions of the aerosol mask (see Fig. 1) have also been indicated. This graph confirms that the three FF vs. AOT regions selected are well suited to identify the three aerosol types. This is because the distribution of points in the three regions of Fig. 11 (maritime, continental and dust) shows no tendency to overlap. Conversely, a concentration 
Table 2b. As in Table 2a but for the Spring season $(S=M A M)$.

\begin{tabular}{|c|c|c|c|c|c|c|c|}
\hline \multirow[t]{2}{*}{ Sector } & \multicolumn{3}{|c|}{$\begin{array}{l}\operatorname{AOT}_{M A M, \text { SEC }, \text { type }} \pm \text { s. d. } \\
\text { (AOT }_{M A M, \text { type in SEC } \pm \text { s. d.) }}\end{array}$} & \multicolumn{3}{|c|}{$\begin{array}{c}\mathrm{AOT}_{M A M, \text { SEC, type }}^{*} \pm \mathrm{s.d} . \\
\left(\mathrm{AOT}^{*}{ }_{M A M, \mathrm{SEC}, \text { type }} / \mathrm{AOT}_{M A M, \text { sEC }}\right) \text { in \% }\end{array}$} & \multirow[t]{2}{*}{$\begin{array}{c}\text { AOT }_{M A M, \text { SEC }} \\
\pm \text { s. d. }\end{array}$} \\
\hline & dust & continental & maritime & dust & continental & maritime & \\
\hline 1 & $\begin{array}{c}0.30 \pm 0.12 \\
(0.40 \pm 0.14)\end{array}$ & $\begin{array}{c}0.14 \pm 0.04 \\
(0.14 \pm 0.04)\end{array}$ & $\begin{array}{c}0.17 \pm 0.03 \\
(0.17 \pm 0.03)\end{array}$ & $\begin{array}{c}0.03 \pm 0.02 \\
(18 \%)\end{array}$ & $\begin{array}{c}0.06 \pm 0.03 \\
(35 \%)\end{array}$ & $\begin{array}{c}0.08 \pm 0.03 \\
(47 \%)\end{array}$ & $0.17 \pm 0.03$ \\
\hline 2 & $\begin{array}{c}0.35 \pm 0.28 \\
(0.55 \pm 0.35)\end{array}$ & $\begin{array}{c}0.16 \pm 0.05 \\
(0.16 \pm 0.05)\end{array}$ & $\begin{array}{c}0.15 \pm 0.03 \\
(0.16 \pm 0.03)\end{array}$ & $\begin{array}{c}0.04 \pm 0.04 \\
(22 \%)\end{array}$ & $\begin{array}{c}0.08 \pm 0.04 \\
(44 \%)\end{array}$ & $\begin{array}{c}0.06 \pm 0.03 \\
(34 \%)\end{array}$ & $0.18 \pm 0.05$ \\
\hline 3 & $\begin{array}{c}0.34 \pm 0.15 \\
(0.46 \pm 0.17)\end{array}$ & $\begin{array}{c}0.12 \pm 0.03 \\
(0.12 \pm 0.03)\end{array}$ & $\begin{array}{c}0.16 \pm 0.03 \\
(0.16 \pm 0.03)\end{array}$ & $\begin{array}{c}0.04 \pm 0.03 \\
(24 \%)\end{array}$ & $\begin{array}{c}0.05 \pm 0.02 \\
(29 \%)\end{array}$ & $\begin{array}{c}0.08 \pm 0.03 \\
(47 \%)\end{array}$ & $0.17 \pm 0.03$ \\
\hline 4 & $\begin{array}{c}0.56 \pm 0.28 \\
(0.65 \pm 0.30)\end{array}$ & $\begin{array}{c}0.16 \pm 0.05 \\
(0.16 \pm 0.05)\end{array}$ & $\begin{array}{c}0.16 \pm 0.03 \\
(0.17 \pm 0.03)\end{array}$ & $\begin{array}{c}0.09 \pm 0.07 \\
(41 \%)\end{array}$ & $\begin{array}{c}0.06 \pm 0.03 \\
(27 \%)\end{array}$ & $\begin{array}{c}0.07 \pm 0.02 \\
(32 \%)\end{array}$ & $0.22 \pm 0.07$ \\
\hline 5 & $\begin{array}{c}0.30 \pm 0.11 \\
(0.51 \pm 0.14)\end{array}$ & $\begin{array}{c}0.15 \pm 0.11 \\
(0.16 \pm 0.11)\end{array}$ & $\begin{array}{c}0.13 \pm 0.04 \\
(0.17 \pm 0.05)\end{array}$ & $\begin{array}{c}0.05 \pm 0.04 \\
(29 \%)\end{array}$ & $\begin{array}{c}0.08 \pm 0.10 \\
(47 \%)\end{array}$ & $\begin{array}{c}0.04 \pm 0.02 \\
(24 \%)\end{array}$ & $0.17 \pm 0.10$ \\
\hline 6 & $\begin{array}{c}0.36 \pm 0.12 \\
(0.46 \pm 0.14)\end{array}$ & $\begin{array}{c}0.12 \pm 0.04 \\
(0.13 \pm 0.04)\end{array}$ & $\begin{array}{c}0.16 \pm 0.02 \\
(0.16 \pm 0.03)\end{array}$ & $\begin{array}{c}0.06 \pm 0.04 \\
(33 \%)\end{array}$ & $\begin{array}{c}0.04 \pm 0.02 \\
(22 \%)\end{array}$ & $\begin{array}{c}0.08 \pm 0.03 \\
(45 \%)\end{array}$ & $0.18 \pm 0.04$ \\
\hline 7 & $\begin{array}{c}0.54 \pm 0.18 \\
(0.57 \pm 0.18)\end{array}$ & $\begin{array}{c}0.15 \pm 0.05 \\
(0.15 \pm 0.05)\end{array}$ & $\begin{array}{c}0.16 \pm 0.02 \\
(0.17 \pm 0.02)\end{array}$ & $\begin{array}{c}0.12 \pm 0.06 \\
(48 \%)\end{array}$ & $\begin{array}{c}0.05 \pm 0.02 \\
(20 \%)\end{array}$ & $\begin{array}{c}0.08 \pm 0.02 \\
(32 \%)\end{array}$ & $0.25 \pm 0.06$ \\
\hline 8 & $\begin{array}{c}0.47 \pm 0.20 \\
(0.55 \pm 0.22)\end{array}$ & $\begin{array}{c}0.12 \pm 0.05 \\
(0.14 \pm 0.06)\end{array}$ & $\begin{array}{c}0.15 \pm 0.03 \\
(0.17 \pm 0.03)\end{array}$ & $\begin{array}{c}0.12 \pm 0.11 \\
(52 \%)\end{array}$ & $\begin{array}{c}0.04 \pm 0.03 \\
(17 \%)\end{array}$ & $\begin{array}{c}0.07 \pm 0.03 \\
(31 \%)\end{array}$ & $0.23 \pm 0.11$ \\
\hline 9 & $\begin{array}{c}0.63 \pm 0.28 \\
(0.65 \pm 0.28)\end{array}$ & $\begin{array}{c}0.14 \pm 0.05 \\
(0.15 \pm 0.05)\end{array}$ & $\begin{array}{c}0.16 \pm 0.02 \\
(0.16 \pm 0.02)\end{array}$ & $\begin{array}{c}0.17 \pm 0.10 \\
(61 \%)\end{array}$ & $\begin{array}{c}0.03 \pm 0.02 \\
(11 \%)\end{array}$ & $\begin{array}{c}0.08 \pm 0.02 \\
(28 \%)\end{array}$ & $0.28 \pm 0.09$ \\
\hline 10 & $\begin{array}{c}0.54 \pm 0.31 \\
(0.61 \pm 0.33)\end{array}$ & $\begin{array}{c}0.10 \pm 0.06 \\
(0.13 \pm 0.07)\end{array}$ & $\begin{array}{c}0.16 \pm 0.03 \\
(0.17 \pm 0.03)\end{array}$ & $\begin{array}{c}0.14 \pm 0.13 \\
(54 \%)\end{array}$ & $\begin{array}{c}0.02 \pm 0.02 \\
(8 \%)\end{array}$ & $\begin{array}{c}0.10 \pm 0.03 \\
(38 \%)\end{array}$ & $0.26 \pm 0.12$ \\
\hline
\end{tabular}

of points along the regions limits would have been found for a wrong choice of the three regions thresholds. In particular, a clear-cut distinction between continental and desert dust aerosol emerges, not only in terms of fine fraction (imposed) but also in terms of AOT. This means that, even if high AOT can be associated to some episodes of continental aerosol transport, these conditions are I) not frequent (mean continental AOT $<0.3$ and mean desert dust AOT $>0.4$ in Fig. 11 and Table 2), and II) well discernible from dust events by the aerosol mask (definite distinction between continental and dust points in the FF vs. AOT space of Fig. 11).

\subsection{Estimation of the aerosol mass loading}

Starting from AOT values, estimates of the column aerosol loading, $\mathrm{M}\left(\mathrm{g} / \mathrm{m}^{2}\right)$, can be derived employing an appropriate conversion factor, generally referred to as the mass-toextinction efficiency, $\alpha=$ AOT $/ \mathrm{M}\left(\mathrm{m}^{2} / \mathrm{g}\right)$. Since both AOT and $\mathbf{M}$ depend on particles physical and optical properties, substantially different $\alpha$ are associated to different aerosol types. An updated compilation of $\alpha$ values can be found in the last IPCC report (Table 5.1 in Penner et al., 2001) where these are classified on the basis of geographical region and/or aerosol type. For example, minimum and maximum values of $\alpha=1.8 \pm 0.5 \mathrm{~m}^{2} / \mathrm{g}$ and $\alpha=3.8 \pm 1.0 \mathrm{~m}^{2} / \mathrm{g}$ are there reported for maritime aerosols, corresponding to "Pacific marine accumulation and coarse mode", and "Atlantic marine", 
Table 2c. As in Table 2a but for the Summer season $(S=J J A)$.

\begin{tabular}{|c|c|c|c|c|c|c|c|}
\hline \multirow[t]{2}{*}{ Sector } & \multicolumn{3}{|c|}{$\begin{array}{l}\operatorname{AOT}_{J J A, \text { SEC, type }} \pm \text { s. d. } \\
\left(\mathrm{AOT}_{J J A, \text { type in SEC }} \pm \text { s. d.) }\right.\end{array}$} & \multicolumn{3}{|c|}{$\begin{array}{c}\operatorname{AOT}_{J J A, \text { SEC, type }}^{*} \pm \text { s. d. } \\
\left(\mathrm{AOT}_{J J A, \text { SEC, type }}^{*} / \mathrm{AOT}_{J J A}, \mathrm{SEC}\right) \text { in \% }\end{array}$} & \multirow[t]{2}{*}{$\begin{array}{l}\operatorname{AOT}_{J J A, \mathrm{SEC}} \\
\quad \pm \text { s. d. }\end{array}$} \\
\hline & dust & continental & maritime & dust & continental & maritime & \\
\hline 1 & $\begin{array}{c}0.40 \pm 0.14 \\
(0.52 \pm 0.16)\end{array}$ & $\begin{array}{c}0.22 \pm 0.06 \\
(0.22 \pm 0.06)\end{array}$ & $\begin{array}{c}0.15 \pm 0.03 \\
(0.15 \pm 0.03)\end{array}$ & $\begin{array}{c}0.05 \pm 0.04 \\
(24 \%)\end{array}$ & $\begin{array}{c}0.09 \pm 0.04 \\
(43 \%)\end{array}$ & $\begin{array}{c}0.07 \pm 0.02 \\
(33 \%)\end{array}$ & $0.21 \pm 0.04$ \\
\hline 2 & $\begin{array}{c}0.30 \pm 0.23 \\
(0.59 \pm 0.33)\end{array}$ & $\begin{array}{c}0.22 \pm 0.06 \\
(0.23 \pm 0.06)\end{array}$ & $\begin{array}{c}0.12 \pm 0.04 \\
(0.14 \pm 0.04)\end{array}$ & $\begin{array}{c}0.03 \pm 0.04 \\
(15 \%)\end{array}$ & $\begin{array}{c}0.13 \pm 0.06 \\
(65 \%)\end{array}$ & $\begin{array}{c}0.04 \pm 0.02 \\
(20 \%)\end{array}$ & $0.20 \pm 0.05$ \\
\hline 3 & $\begin{array}{c}0.44 \pm 0.12 \\
(0.49 \pm 0.13)\end{array}$ & $\begin{array}{c}0.20 \pm 0.05 \\
(0.20 \pm 0.05)\end{array}$ & $\begin{array}{c}0.16 \pm 0.03 \\
(0.16 \pm 0.03)\end{array}$ & $\begin{array}{c}0.10 \pm 0.06 \\
(42 \%)\end{array}$ & $\begin{array}{c}0.07 \pm 0.04 \\
(29 \%)\end{array}$ & $\begin{array}{c}0.07 \pm 0.02 \\
(29 \%)\end{array}$ & $0.24 \pm 0.05$ \\
\hline 4 & $\begin{array}{c}0.44 \pm 0.16 \\
(0.55 \pm 0.18)\end{array}$ & $\begin{array}{c}0.20 \pm 0.06 \\
(0.21 \pm 0.06)\end{array}$ & $\begin{array}{c}0.13 \pm 0.03 \\
(0.14 \pm 0.03)\end{array}$ & $\begin{array}{c}0.06 \pm 0.04 \\
(28 \%)\end{array}$ & $\begin{array}{c}0.10 \pm 0.05 \\
(48 \%)\end{array}$ & $\begin{array}{c}0.05 \pm 0.02 \\
(24 \%)\end{array}$ & $0.21 \pm 0.05$ \\
\hline 5 & $\begin{array}{c}0.06 \pm 0.03 \\
(0.39 \pm 0.07)\end{array}$ & $\begin{array}{c}0.25 \pm 0.06 \\
(0.28 \pm 0.06)\end{array}$ & $\begin{array}{c}0.13 \pm 0.04 \\
(0.16 \pm 0.04)\end{array}$ & $\begin{array}{c}0.01 \pm 0.01 \\
(5 \%)\end{array}$ & $\begin{array}{c}0.15 \pm 0.07 \\
(75 \%)\end{array}$ & $\begin{array}{c}0.04 \pm 0.02 \\
(20 \%)\end{array}$ & $0.20 \pm 0.06$ \\
\hline 6 & $\begin{array}{c}0.54 \pm 0.15 \\
(0.59 \pm 0.16)\end{array}$ & $\begin{array}{c}0.17 \pm 0.08 \\
(0.20 \pm 0.09)\end{array}$ & $\begin{array}{c}0.15 \pm 0.04 \\
(0.15 \pm 0.04)\end{array}$ & $\begin{array}{c}0.18 \pm 0.09 \\
(64 \%)\end{array}$ & $\begin{array}{c}0.03 \pm 0.02 \\
(11 \%)\end{array}$ & $\begin{array}{c}0.07 \pm 0.03 \\
(25 \%)\end{array}$ & $0.28 \pm 0.08$ \\
\hline 7 & $\begin{array}{c}0.48 \pm 0.12 \\
(0.53 \pm 0.12)\end{array}$ & $\begin{array}{c}0.21 \pm 0.05 \\
(0.21 \pm 0.05)\end{array}$ & $\begin{array}{c}0.16 \pm 0.03 \\
(0.16 \pm 0.03)\end{array}$ & $\begin{array}{c}0.10 \pm 0.06 \\
(42 \%)\end{array}$ & $\begin{array}{c}0.07 \pm 0.04 \\
(29 \%)\end{array}$ & $\begin{array}{c}0.07 \pm 0.02 \\
(29 \%)\end{array}$ & $0.24 \pm 0.04$ \\
\hline 8 & $\begin{array}{c}0.20 \pm 0.07 \\
(0.41 \pm 0.10)\end{array}$ & $\begin{array}{c}0.22 \pm 0.07 \\
(0.28 \pm 0.08)\end{array}$ & $\begin{array}{c}0.15 \pm 0.04 \\
(0.17 \pm 0.04)\end{array}$ & $\begin{array}{c}0.03 \pm 0.03 \\
(15 \%)\end{array}$ & $\begin{array}{c}0.09 \pm 0.06 \\
(45 \%)\end{array}$ & $\begin{array}{c}0.08 \pm 0.04 \\
(40 \%)\end{array}$ & $0.20 \pm 0.05$ \\
\hline 9 & $\begin{array}{c}0.47 \pm 0.12 \\
(0.49 \pm 0.13)\end{array}$ & $\begin{array}{c}0.19 \pm 0.04 \\
(0.20 \pm 0.05)\end{array}$ & $\begin{array}{c}0.17 \pm 0.02 \\
(0.17 \pm 0.02)\end{array}$ & $\begin{array}{c}0.10 \pm 0.06 \\
(43 \%)\end{array}$ & $\begin{array}{c}0.05 \pm 0.03 \\
(22 \%)\end{array}$ & $\begin{array}{c}0.08 \pm 0.03 \\
(35 \%)\end{array}$ & $0.23 \pm 0.05$ \\
\hline 10 & $\begin{array}{c}0.27 \pm 0.13 \\
(0.41 \pm 0.16)\end{array}$ & $\begin{array}{c}0.13 \pm 0.07 \\
(0.20 \pm 0.08)\end{array}$ & $\begin{array}{c}0.17 \pm 0.03 \\
(0.18 \pm 0.03)\end{array}$ & $\begin{array}{c}0.05 \pm 0.05 \\
(25 \%)\end{array}$ & $\begin{array}{c}0.03 \pm 0.03 \\
(15 \%)\end{array}$ & $\begin{array}{c}0.12 \pm 0.04 \\
(60 \%)\end{array}$ & $0.20 \pm 0.04$ \\
\hline
\end{tabular}

respectively. For continental aerosols, minimum and maximum values of $\alpha=1.00 \pm 0.08 \mathrm{~m}^{2} / \mathrm{g}$ and $\alpha=3.5 \pm 1.2 \mathrm{~m}^{2} / \mathrm{g}$ are given, corresponding respectively to "background continental - accumulation and coarse mode" and "polluted continental". The $\alpha$ parameter being very sensitive to the particle size distribution, a large variability (more than an order of magnitude) of mass-to-extinction efficiencies of desert dust can be found in literature (e.g. Moulin et al., 1997; Cachorro and Tanré, 1997). This large variability is explained considering that it includes values from different dust models and measurement techniques, and, in the latter case, different distance from the sources, different aerosol sampling levels, different dust load conditions in the atmosphere, etc. Over the Mediterranean, Dulac et al. (1992a, 1992b) derived $\alpha$ in the range $0.6-0.9 \mathrm{~m}^{2} / \mathrm{g}$ from desert aerosol samples col- lected at the surface level in Corsica (France). To our knowledge no specific value is reported for continental and maritime aerosol types in this region. We then performed an original investigation to evaluate the $\alpha$ values typical of the three Mediterranean aerosol types addressed in this study. To this purpose, we employed 1) a large statistics of lidar measurements to determine typical aerosol extinction coefficients and 2) aerosol models to link such aerosol extinction values to the relevant mass. These models were specifically developed to invert lidar measurements in maritime, continental and desert-dust conditions (Barnaba and Gobbi, 2001; Barnaba and Gobbi, 2004). Both lidar observations and numerical computations refer to the wavelength of $532 \mathrm{~nm}$, i.e. very close to the $550 \mathrm{~nm}$ MODIS one. Lidar observations performed at Mediterranean sites under appropriate aerosol load 
Table 2d. As in Table 2a but for the Fall season $(S=S O N)$.

\begin{tabular}{|c|c|c|c|c|c|c|c|}
\hline \multirow[t]{2}{*}{ Sector } & \multicolumn{3}{|c|}{$\begin{array}{l}\operatorname{AOT}_{S O N, \text { SEC, type }} \pm \text { s. d. } \\
\text { (AOT }_{S O N, \text { type in SEC } \pm \text { s. d.) }}\end{array}$} & \multicolumn{3}{|c|}{$\begin{array}{c}\text { AOT }_{S O N, \text { SEC, type }}^{*} \pm \text { s. d. } \\
\left(\mathrm{AOT}_{S O N, \text { SEC, type }}^{*} / \mathrm{AOT}_{S O N, \mathrm{SEC}) \text { in \% }}\right.\end{array}$} & \multirow[t]{2}{*}{$\begin{array}{c}\operatorname{AOT}_{S O N, \text { SEC }} \\
\pm \text { s. d. }\end{array}$} \\
\hline & dust & continental & maritime & dust & continental & maritime & \\
\hline 1 & $\begin{array}{c}0.38 \pm 0.06 \\
(0.41 \pm 0.07)\end{array}$ & $\begin{array}{c}0.16 \pm 0.08 \\
(0.24 \pm 0.09)\end{array}$ & $\begin{array}{c}0.13 \pm 0.02 \\
(0.13 \pm 0.02)\end{array}$ & $\begin{array}{c}0.04 \pm 0.02 \\
(26 \%)\end{array}$ & $\begin{array}{c}0.01 \pm 0.01 \\
(7 \%)\end{array}$ & $\begin{array}{c}0.10 \pm 0.02 \\
(67 \%)\end{array}$ & $0.15 \pm 0.02$ \\
\hline 2 & $\begin{array}{c}0.39 \pm 0.12 \\
(0.46 \pm 0.13)\end{array}$ & $\begin{array}{c}0.21 \pm 0.10 \\
(0.25 \pm 0.11)\end{array}$ & $\begin{array}{c}0.12 \pm 0.02 \\
(0.12 \pm 0.02)\end{array}$ & $\begin{array}{c}0.04 \pm 0.03 \\
(25 \%)\end{array}$ & $\begin{array}{c}0.03 \pm 0.02 \\
(19 \%)\end{array}$ & $\begin{array}{c}0.09 \pm 0.02 \\
(56 \%)\end{array}$ & $0.16 \pm 0.04$ \\
\hline 3 & $\begin{array}{c}0.43 \pm 0.10 \\
(0.45 \pm 0.10)\end{array}$ & $\begin{array}{c}0.13 \pm 0.07 \\
(0.22 \pm 0.10)\end{array}$ & $\begin{array}{c}0.14 \pm 0.02 \\
(0.14 \pm 0.02)\end{array}$ & $\begin{array}{c}0.07 \pm 0.04 \\
(37 \%)\end{array}$ & $\begin{array}{c}0.01 \pm 0.01 \\
(5 \%)\end{array}$ & $\begin{array}{c}0.11 \pm 0.02 \\
(58 \%)\end{array}$ & $0.19 \pm 0.03$ \\
\hline 4 & $\begin{array}{c}0.48 \pm 0.24 \\
(0.51 \pm 0.24)\end{array}$ & $\begin{array}{c}0.17 \pm 0.07 \\
(0.23 \pm 0.08)\end{array}$ & $\begin{array}{c}0.13 \pm 0.02 \\
(0.13 \pm 0.02)\end{array}$ & $\begin{array}{c}0.06 \pm 0.04 \\
(33 \%)\end{array}$ & $\begin{array}{c}0.02 \pm 0.01 \\
(11 \%)\end{array}$ & $\begin{array}{c}0.10 \pm 0.02 \\
(56 \%)\end{array}$ & $0.18 \pm 0.03$ \\
\hline 5 & $\begin{array}{c}0.29 \pm 0.05 \\
(0.40 \pm 0.06)\end{array}$ & $\begin{array}{c}0.27 \pm 0.10 \\
(0.30 \pm 0.11)\end{array}$ & $\begin{array}{c}0.14 \pm 0.02 \\
(0.14 \pm 0.02)\end{array}$ & $\begin{array}{c}0.03 \pm 0.03 \\
(18 \%)\end{array}$ & $\begin{array}{c}0.05 \pm 0.05 \\
(29 \%)\end{array}$ & $\begin{array}{c}0.09 \pm 0.03 \\
(53 \%)\end{array}$ & $0.17 \pm 0.05$ \\
\hline 6 & $\begin{array}{c}0.46 \pm 0.10 \\
(0.48 \pm 0.10)\end{array}$ & $\begin{array}{c}0.16 \pm 0.11 \\
(0.34 \pm 0.16)\end{array}$ & $\begin{array}{c}0.15 \pm 0.02 \\
(0.15 \pm 0.02)\end{array}$ & $\begin{array}{c}0.12 \pm 0.06 \\
(52 \%)\end{array}$ & $\begin{array}{c}0.01 \pm 0.02 \\
(4 \%)\end{array}$ & $\begin{array}{c}0.10 \pm 0.02 \\
(44 \%)\end{array}$ & $0.23 \pm 0.05$ \\
\hline 7 & $\begin{array}{c}0.46 \pm 0.07 \\
(0.47 \pm 0.07)\end{array}$ & $\begin{array}{c}0.18 \pm 0.07 \\
(0.23 \pm 0.09)\end{array}$ & $\begin{array}{c}0.15 \pm 0.02 \\
(0.15 \pm 0.02)\end{array}$ & $\begin{array}{c}0.10 \pm 0.05 \\
(45.5 \%)\end{array}$ & $\begin{array}{c}0.02 \pm 0.01 \\
(9 \%)\end{array}$ & $\begin{array}{c}0.10 \pm 0.02 \\
(45.5 \%)\end{array}$ & $0.22 \pm 0.04$ \\
\hline 8 & $\begin{array}{c}0.31 \pm 0.06 \\
(0.40 \pm 0.07)\end{array}$ & $\begin{array}{c}0.19 \pm 0.08 \\
(0.25 \pm 0.09)\end{array}$ & $\begin{array}{c}0.15 \pm 0.03 \\
(0.15 \pm 0.03)\end{array}$ & $\begin{array}{c}0.04 \pm 0.03 \\
(23 \%)\end{array}$ & $\begin{array}{c}0.02 \pm 0.02 \\
(12 \%)\end{array}$ & $\begin{array}{c}0.11 \pm 0.03 \\
(65 \%)\end{array}$ & $0.17 \pm 0.04$ \\
\hline 9 & $\begin{array}{c}0.46 \pm 0.08 \\
(0.47 \pm 0.08)\end{array}$ & $\begin{array}{c}0.19 \pm 0.08 \\
(0.22 \pm 0.09)\end{array}$ & $\begin{array}{c}0.17 \pm 0.02 \\
(0.17 \pm 0.02)\end{array}$ & $\begin{array}{c}0.13 \pm 0.06 \\
(50 \%)\end{array}$ & $\begin{array}{c}0.02 \pm 0.01 \\
(8 \%)\end{array}$ & $\begin{array}{c}0.11 \pm 0.02 \\
(42 \%)\end{array}$ & $0.26 \pm 0.05$ \\
\hline 10 & $\begin{array}{c}0.38 \pm 0.08 \\
(0.41 \pm 0.08)\end{array}$ & $\begin{array}{c}0.16 \pm 0.08 \\
(0.21 \pm 0.09)\end{array}$ & $\begin{array}{c}0.15 \pm 0.02 \\
(0.15 \pm 0.02)\end{array}$ & $\begin{array}{c}0.05 \pm 0.03 \\
(28 \%)\end{array}$ & $\begin{array}{c}0.01 \pm 0.01 \\
(5 \%)\end{array}$ & $\begin{array}{c}0.12 \pm 0.02 \\
(67 \%)\end{array}$ & $0.18 \pm 0.03$ \\
\hline
\end{tabular}

conditions have been considered. In particular, lidar measurements for the year 2001 collected in a semi-urban site at the outskirts of Rome $\left(41.8^{\circ} \mathrm{N}, 12.6^{\circ} \mathrm{E}\right)$, Italy (Gobbi et al., 2004) were used to derive a suitable $\alpha$ value of continental aerosols $\left(\alpha_{\text {cont }}\right)$. Considering the mean distance between the Rome site and the Saharan region (about 1000-1500 km), lidar measurements recorded in Rome during the seven major dust events registered in 2001 were used as representative of transported desert dust conditions to derive a typical Mediterranean $\alpha_{\text {dust }}$. Finally, lidar observations performed in Crete $\left(35.5^{\circ} \mathrm{N}, 23.7^{\circ} \mathrm{E}\right.$ ), Greece, in May 1999 (Gobbi et al., 2000) were employed as representative of Mediterranean maritime conditions to derive $\alpha_{\text {mar }}$. A detailed description of the procedure employed to derive the three investigated mass-to-extinction efficiencies is given in Appendix A. The resulting coefficients are: $\alpha_{\text {cont }}=2.80 \mathrm{~m}^{2} / \mathrm{g}, \alpha_{\text {dust }}=1.36 \mathrm{~m}^{2} / \mathrm{g}$ and $\alpha_{\text {mar }}=1.85 \mathrm{~m}^{2} / \mathrm{g}$ for continental, desert dust and maritime aerosol, respectively.

Both $\alpha_{\text {cont }}$ and $\alpha_{\text {mar }}$ fall within the variability range of IPCC reported above. Our $\alpha_{\text {dust }}$ value is somewhat higher than the one derived by Dulac et al. (1992a) in the Northwestern Mediterranean $\left(\alpha=1 /\left(1.13 \mathrm{~g} / \mathrm{m}^{2}\right)=0.88 \mathrm{~m}^{2} / \mathrm{g}\right)$ from cascade impactor desert dust samples, i.e. for dust aerosol sampled at the surface level (note that, for a given AOT, the higher $\alpha$ the lower the dust mass). Some discussion on the $\alpha_{\text {dust }}$ value obtained is given ahead in this Section.

Based on the derived mass-to-extinction efficiencies, the mean seasonal $(S)$ maritime, continental and desert dust mass loads, evaluated for each of the ten sectors (SEC) of Fig. 10 (i.e. $M_{S, \text { SEC,type }}^{*}=$ AOT $_{S, \text { SEC,type }}{ }^{*} / \alpha_{\text {type }}$, expressed in 


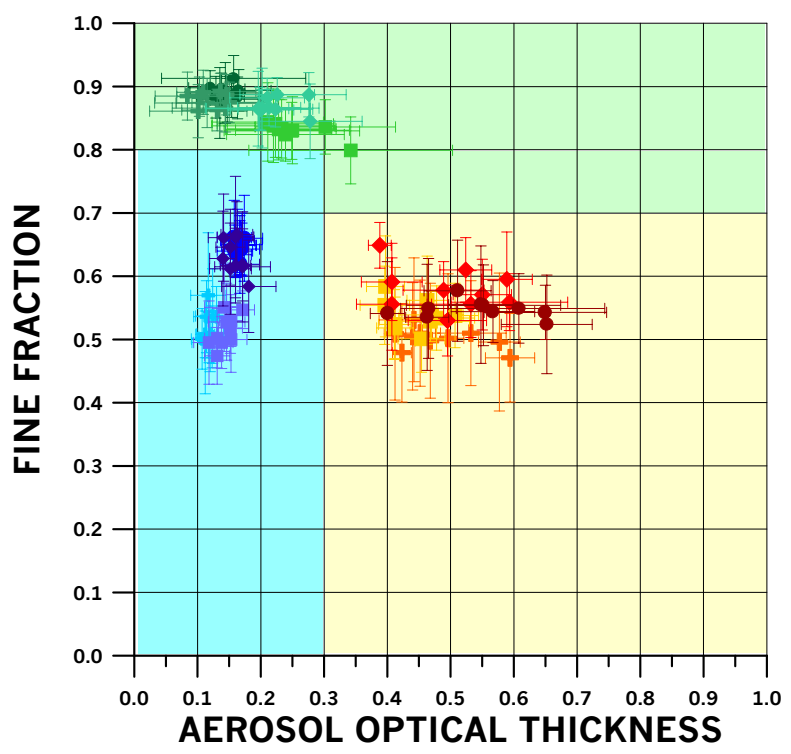

Fig. 11. Mean seasonal FF vs. AOT values characterizing each aerosol type in the ten Mediterranean sectors of Fig. 10 (i.e.

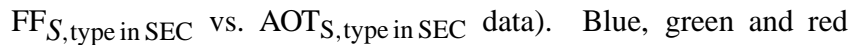
points refer to maritime, continental and desert dust aerosol, respectively. Different symbols are used to indicate the different seasons (i.e. crosses, bullets, diamonds and squares refer to DJF, MAM, JJA and $S O N$, respectively). The aerosol mask thresholds of Fig. 1 are also indicated in the graph.

Table 3. Seasonal average values of the estimated daily atmospheric aerosol mass load (ktons/day) over the Mediterranean basin, for each aerosol type. The total value (ktons, last row) indicates the total suspended aerosol mass in the year 2001 (derived as Total=Mean $\times 4 \times 90$, being 4 the number of seasons per year and about 90 the number of days per season).

\begin{tabular}{cccc}
\hline \multirow{2}{*}{ Season } & \multicolumn{3}{c}{ Aerosol mass } \\
& Desert dust & Continental & Maritime \\
\hline$D J F$ & 40 & 19 & 106 \\
$M A M$ & 180 & 37 & 102 \\
$J J A$ & 131 & 60 & 99 \\
SON & 126 & 15 & 136 \\
Mean \pm s.d. & $119 \pm 58$ & $33 \pm 21$ & $111 \pm 17$ \\
Total (year) & $4.3 \mathrm{E}+04$ & $1.2 \mathrm{E}+04$ & $4.0 \mathrm{E}+04$ \\
\hline
\end{tabular}

$\mathrm{g} / \mathrm{m}^{2}$ ) are shown in Fig. 12. Here, sectors corresponding to Western $(\mathrm{SEC}=1,3,6)$, Central $(\mathrm{SEC}=2,4,7,9)$ and Eastern $(\mathrm{SEC}=5,8,10)$ Mediterranean basin have been reported in separated plots (first, second and third column of Fig. 12, respectively) in order to better highlight the regional (longitudinal) differences. Moreover, this representation allows easy evaluation the meridional gradient of both the continental and desert dust aerosols.
Considering the area of each sector, mean seasonal aerosol mass loads (i.e. $\sum_{\mathrm{SEC}} M_{S, \mathrm{SEC} \text {,type }}^{*} \times \mathrm{SEC}_{\text {Area }}$ ) were computed and are summarized in Table 3. For each aerosol type, seasonal mass values in Table 3 can be considered as the typical load characterizing each day during the season. Table 3 also shows that the total suspended mass of desert dust over the Mediterranean basin in the year $2001\left(4.3 \times 10^{4} \mathrm{ktons}\right)$ is comparable to that of maritime aerosol, although (as already discussed) the former exhibits a seasonal cycle. The almost constant value of the maritime aerosol mass over the seasons (mean value $111 \mathrm{ktons} /$ day associated to a standard deviation, s.d., of 17 Mtons, i.e. $15 \%$ ) can be considered as a further confirmation of the consistency of the aerosol mask scheme presented.

With respect to the total dust load of $4.3 \times 10^{4} \mathrm{ktons}$, this should be considered as a lower limit of the actual value due to the two points described hereafter. 1) To give an estimation of the total dust loaded in the atmosphere during the year, every dust event observed should be considered at its maximum (in terms of both AOT and extent). However, by definition, the seasonal means performed in this study do not capture the dust plumes at their maximum but rather weigh their amplitude all over the dust event. 2) The desert dust mass-to-extinction factor, $\alpha_{\text {dust }}=1.36 \mathrm{~m}^{2} / \mathrm{g}$, is employed here as a mean Mediterranean value. It can be considered as a typical value of long-range transported $(\geq 1000 \mathrm{~km})$ dust. For comparison, $\alpha_{\text {dust }}=0.96 \mathrm{~m}^{2} / \mathrm{g}$ and $\alpha_{\text {dust }}=0.93 \mathrm{~m}^{2} / \mathrm{g}$ were obtained (following the same approach as described in Appendix A) employing lidar observations of Saharan dust plumes observed closer to the source region, i.e. over the Canary Islands (August 2002) and Sicily (July 2003), respectively. On the whole, this variability is expected to produce a maximum dust mass underestimation, $\mathrm{dM} / \mathrm{M}$, of the order of $50 \%$ close to the dust sources $(\mathrm{dM} / \mathrm{M}=[(1 / 0.93$ $1 / 1.36) \mathrm{AOT}] /(1 / 1.36) \mathrm{AOT}) \cong 0.47)$.

Finally, some comparisons of our results with similar estimates obtained from both modeling studies and observations are given hereafter.

In the case of modeling, the aerosol mass load is obtained by combining source emissions and meteorological data with atmospheric processing (chemistry, transport, etc.). A comprehensive study focusing on aerosol modules of different models was performed by Kinne et al. (2003). In that study, models including at least five aerosol components (sulphate, organic and black carbon, sea salt and dust) were considered and yearly average values of aerosol mass were computed for different regions of the world, including Europe (more precisely North-Eastern Europe). Overall, the authors highlighted significant differences between the different models in terms of aerosol simulated properties in most of the regions addressed. In particular, simulated by seven models, the aerosol mass yearly average, $\mathrm{Y}_{\text {aerm }}$, over Europe was found to range between 0.05 and $0.15 \mathrm{~g} / \mathrm{m}^{2}$, with four models providing $\mathrm{Y}_{\text {aerm }} \leq 0.06 \mathrm{~g} / \mathrm{m}^{2}$ and three models giving 


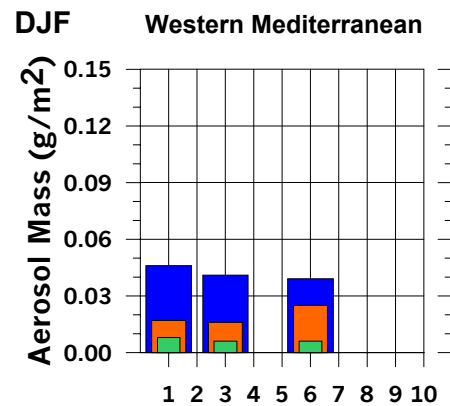

Central Mediterranean

Eastern Mediterranean
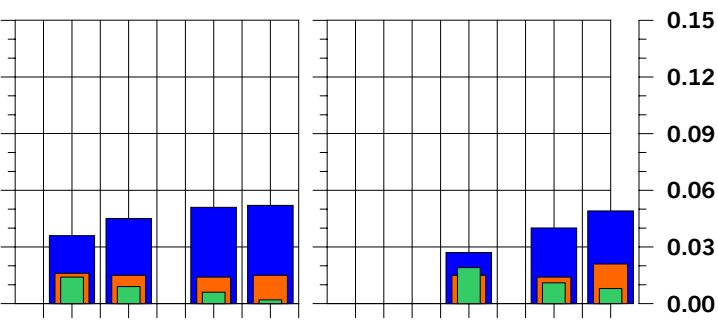

MAM

Western Mediterranean

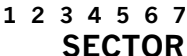

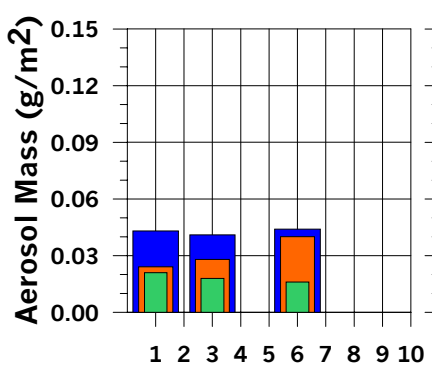

Central Mediterranean

Eastern Mediterranean
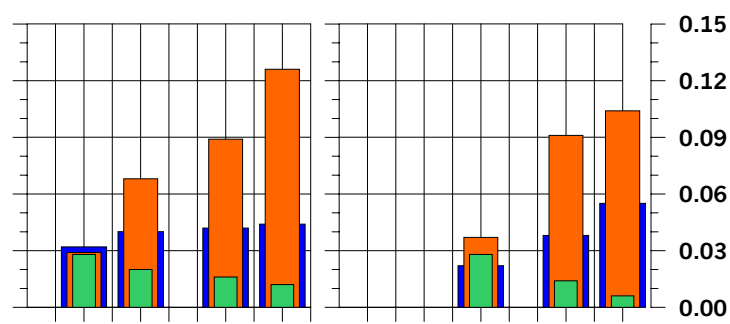

$\begin{array}{llllllllll}1 & 2 & 3 & 4 & 5 & 6 & 7 & 8 & 9 & 10\end{array}$

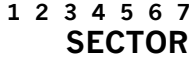

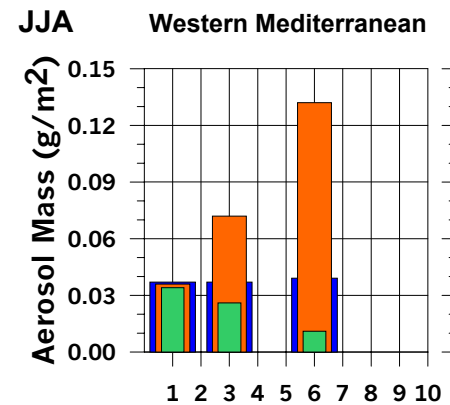

Central Mediterranean
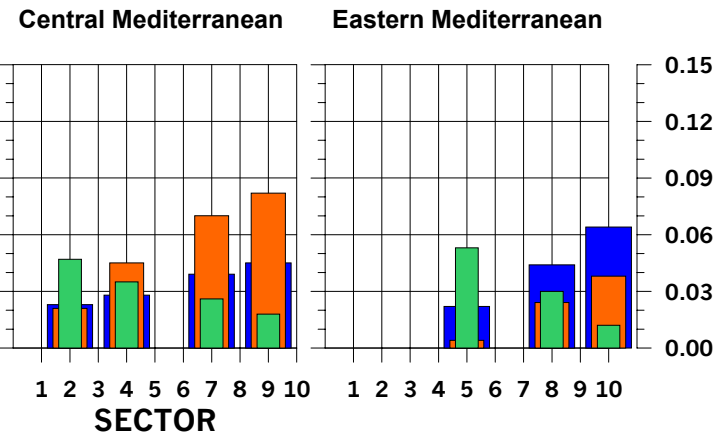

SON SECTOR

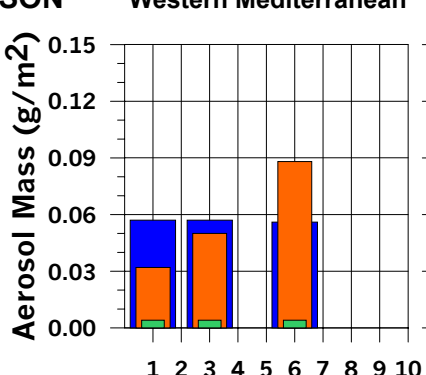

Central Mediterranean

Eastern Mediterranean
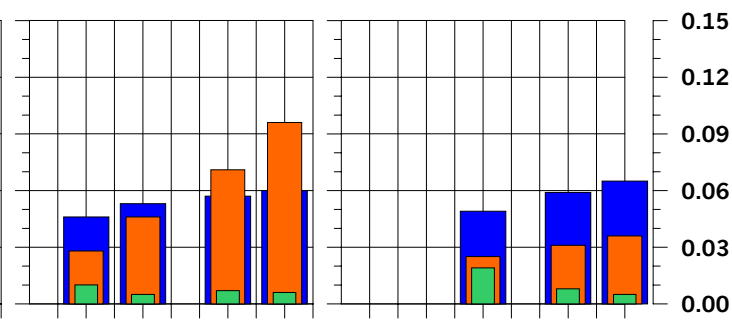

SECTOR

Fig. 12. Mean seasonal $(S=D J F, M A M, J J A$ and $S O N)$ maritime, continental and desert dust mass loads $\left(\mathrm{g} / \mathrm{m}^{2} ; \mathrm{blue}\right.$, green and orange histograms, respectively) in the ten sectors (SEC) of Fig. 10, shown separately for Western (SEC=1, 3, 6), Central (SEC=2, 4, 7, 9) and Eastern (SEC=5, 8, 10) Mediterranean (left, central and right column, respectively).

$Y_{\text {aerm }} \geq 0.09 \mathrm{~g} / \mathrm{m}^{2}$. For comparison, the yearly average of the continental aerosol mass over the whole Mediterranean basin derived from our analysis is $0.014 \mathrm{~g} / \mathrm{m}^{2}$, which becomes $0.023 \mathrm{~g} / \mathrm{m}^{2}$ when the yearly average is restricted to sectors 1,2 , and 5 , i.e. closer to the region investigated by Kinne et al. (2003). It is therefore evident that our value is much lower than the modeled one. However, it should be noted that, as performed over the Mediterranean basin, our estimates are more representative of the continental aerosol export from Europe rather than of the continental aerosol burden over Europe. Moreover, some overestimation of the emissions over Europe (and consequently of the aerosol mass) was also suspected by Kinne et al. (2003) in their study. 
From Kinne et al. (2003) it is also possible to derive an indirect estimate of the yearly average of Saharan dust mass reaching the Mediterranean $\left(\mathrm{Y}_{\text {dustm, Med }}\right)$. In fact, in that study model-derived values of both dust mass emissions from North Africa $\left(\mathrm{Y}_{\text {dustm,emiss }}\right)$ and dust mass outflow towards the Atlantic ( $\left.\mathrm{Y}_{\text {dustm,outfl }}\right)$ are given. As an approximation, we can therefore derive $\mathrm{Y}_{\text {dustm,Med }}=\mathrm{Y}_{\text {dustm,emiss }}-\mathrm{Y}_{\text {dustm,outfl }}$. In this way, we obtain $\mathrm{Y}_{\text {dustm, Med }}$ in the range $0.02-0.55 \mathrm{~g} / \mathrm{m}^{2}$ (with three models giving $\mathrm{Y}_{\text {dustm, Med }} \leq 0.1 \mathrm{~g} / \mathrm{m}^{2}$, two models providing $0.1<\mathrm{Y}_{\text {dustm, Med }}<0.2 \mathrm{~g} / \mathrm{m}^{2}$ and two models with $\mathrm{Y}_{\text {dustm, Med }}>0.3 \mathrm{~g} / \mathrm{m}^{2}$ ).

For comparison, the yearly average of Saharan dust mass over the Mediterranean derived from our analysis is $0.05 \mathrm{~g} / \mathrm{m}^{2}$.

Recently, the desert dust load over the Mediterranean was also estimated by Sciarra et al. (2004) in the framework of the EU-ADIOS (Atmospheric Deposition and Impact of pollutants, key elements and nutrients on the Open Mediterranean Sea) project. In that case, the true color images from the SeaWiFS sensor were visually inspected to identify presence of desert dust, and SeaWiFS AOT values (at $670 \mathrm{~nm}$ ) were converted to dust mass with $\alpha=0.77 \mathrm{~m}^{2} / \mathrm{g}$. Then, monthly averages of dust load were derived for the Western, Central and Eastern Mediterranean (note that the definition of such regions is slightly different from ours). Taking into account the relative weight of the three regions in the whole basin (R. Sciarra, personal communication), the yearly average dust mass over the whole Mediterranean can be computed. For the year 2001 this is $0.036 \mathrm{~g} / \mathrm{m}^{2}$, i.e. within $30 \%$ of our value $\left(0.05 \mathrm{~g} / \mathrm{m}^{2}\right)$. The corresponding seasonal values are: $0.024 \mathrm{~g} / \mathrm{m}^{2}$ in $D J F, 0.065 \mathrm{~g} / \mathrm{m}^{2}$ in $M A M, 0.030 \mathrm{~g} / \mathrm{m}^{2}$ in $J J A$ and $0.026 \mathrm{~g} / \mathrm{m}^{2}$ in $S O N$. In that order, our analysis provides the following results: $0.017 \mathrm{~g} / \mathrm{m}^{2}$ in $D J F, 0.076 \mathrm{~g} / \mathrm{m}^{2}$ in MAM, $0.055 \mathrm{~g} / \mathrm{m}^{2}$ in $J J A$ and $0.053 \mathrm{~g} / \mathrm{m}^{2}$ in $S O N$.

\section{Conclusions}

One year (2001) of aerosol optical thickness (AOT, at $550 \mathrm{~nm}$ ) data from the MODIS instrument (NASA-Terra) were analyzed in order to evaluate the aerosol seasonal and geographical variability over the Mediterranean region. This study highlighted an evident AOT seasonal cycle over the whole Mediterranean region, with minimum and maximum values in Winter (AOT mainly below 0.15) and Summer (AOT mainly above 0.2 ), respectively. Over land, this study shows that, even when seasonal averages are addressed, the impact of big cities and/or industrialized areas is well detectable in terms of higher AOT levels. In Europe, the Po Valley (i.e. the most industrialized Italian area) is shown to be particularly affected by high AOT values with respect to the surrounding regions. This is likely to be due to both the high level of aerosol gas precursor emissions and the particular orography of the region (an extended valley bounded to the North, West and South by mountains) that facilitates the pollutants entrapment.

Over ocean, an aerosol mask was implemented to separate the contribution to the total AOT of the three aerosol types prevailing over the Mediterranean basin, i.e. maritime aerosols, continental aerosols (mainly of anthropogenic origin), and Saharan dust. When applied to specific case studies, the aerosol mask showed good correspondence with the actual aerosol field evaluated by means of both true-color satellite images and wind fields. Examination of case studies also highlighted advection of continental and desert dust aerosol to occur at different levels, i.e. mainly within and above the planetary boundary layer, respectively.

Application of the aerosol mask to the whole 2001 dataset allowed to identify some clear features of the atmospheric particulate in the Mediterranean. The export of both continental and dust particles over the basin was found to be important. As expected, continental aerosol were found to impact mainly the coastal regions throughout the year. However, in the warmest seasons (Spring and Summer) these particles were found to impact the whole basin, with a relative contribution to the total AOT up to more than $60 \%$ in the Italian and Greek-Turkish coastal regions. A North-to-South gradient of continental aerosol optical thickness is evident in this case. An opposite South-to-North AOT gradient is associated to Saharan dust export, this latter showing a marked seasonal cycle. In fact, while in Spring maximum dust impact is found in Eastern-Central Mediterranean (dust contribution to AOT $>40 \%$ ), in Summer-Fall a shift to the CentralWestern Mediterranean is observed. In Winter 2001 a residual dust activity is registered in the Western part of the basin while in the South-Eastern Mediterranean the beginning of a "new cycle" is detected.

Atmospheric aerosol mass load estimates were performed applying appropriate mass-to-extinction conversion factors $(\alpha)$ to the seasonal AOT averages of maritime, continental and desert dust particles. The $\alpha$ values employed for the three different aerosol types addressed in this study were specifically derived on the basis of lidar observations and modeling studies. Overall, a total seasonal mean value of $119 \mathrm{ktons}$ of desert dust per day was found to characterize the Mediterranean atmosphere, translating into a total of $4.3 \times 10^{4} \mathrm{ktons}$ of dust in the year 2001. A similar total mass load was found to be associated to maritime aerosol $\left(4.0 \times 10^{4} \mathrm{ktons}\right)$. However, as expected, minimum seasonal variability $(15 \%)$ of aerosol mass was found in the maritime case. This result supports the suitability of the aerosol mask adopted to separate the contribution of three aerosol types. Total suspended mass of continental aerosol over the basin in 2001 is estimated to be 1.2 Mtons.

On the whole, this study provides a quantitative overview of the aerosol seasonal variability over the Mediterranean region, well representing the impact of the different aerosol types over the Mediterranean basin. The AOT data presented 


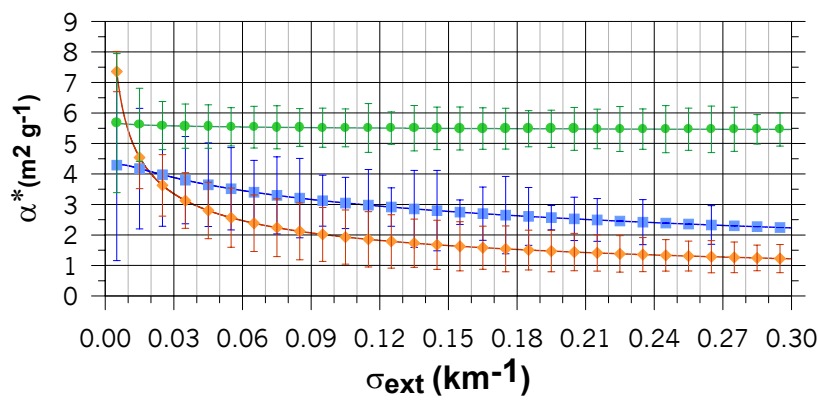

Fig. 13. Modeled behavior of the mass-to-extinction efficiency, $\alpha\left(\mathrm{m}^{2} / \mathrm{g}\right)$, versus the aerosol extinction coefficient, $\sigma_{\text {ext }}\left(\mathrm{km}^{-1}\right)$, computed at the lidar wavelength of $532 \mathrm{~nm}$ for the three different aerosol types: maritime (blue squares), continental (green bullets) and desert dust (orange diamonds). Note that the $\alpha$ parameter is given for unit density (i.e. $\alpha=\alpha^{*}=\sigma_{\text {ext }} / \mathrm{V} \cdot \rho$, with $\rho=1 \mathrm{~g} / \mathrm{cm}^{3}$ ) for each aerosol type. The $\sigma_{\text {ext }}$ values reported in the plot were obtained binning 20000 simulated $\sigma_{\text {ext }}$ with a $0.01 \mathrm{~km}^{-1}$ step. The corresponding mean $\alpha^{*}$ value associated to each bin is reported with its variability ( \pm 1 standard deviation, error bars).

over both land and ocean are thought to be important to provide a base of comparison for chemistry-transport models.

\section{Appendix A: Deriving the mass-to-extinction efficiency values}

Mass-to-extinction efficiency values $(\alpha=$ AOT/M) typical of the three Mediterranean aerosol types addressed in this study were obtained by combining numerical computations based on aerosol models and lidar observations.

As mentioned in Sect. 3.1, AOT and M depending on particles physical and optical properties, $\alpha$ values strongly depend on the specific characteristic of the aerosol type under investigation. In particular, it is:

$$
\begin{aligned}
& \mathrm{AOT}=\int_{z} \sigma_{\mathrm{ext}}(z) d z \\
& \mathrm{M}=(4 / 3) \pi \rho \cdot \int_{r} r^{3} n(r) d r=\rho \cdot \mathrm{V}
\end{aligned}
$$

where $\mathrm{z}$ is the altitude, $\sigma_{\text {ext }}$ is the aerosol extinction coefficient, $\rho$ is the aerosol particle density and $\mathrm{n}(\mathrm{r})$ is the aerosol number size distribution. In Eq. (A2) an assumption of particle sphericity is made.

To derive typical $\alpha$ values, we employed a numerical technique specifically developed to compute mean aerosol optical and physical properties. In particular, mean properties of maritime, desert-dust and continental aerosol were addressed as thoroughly described in Barnaba and Gobbi (2001) and Barnaba and Gobbi (2004). In that procedure, 20000 simulated values of both aerosol extinction, $\sigma_{\text {ext }}$

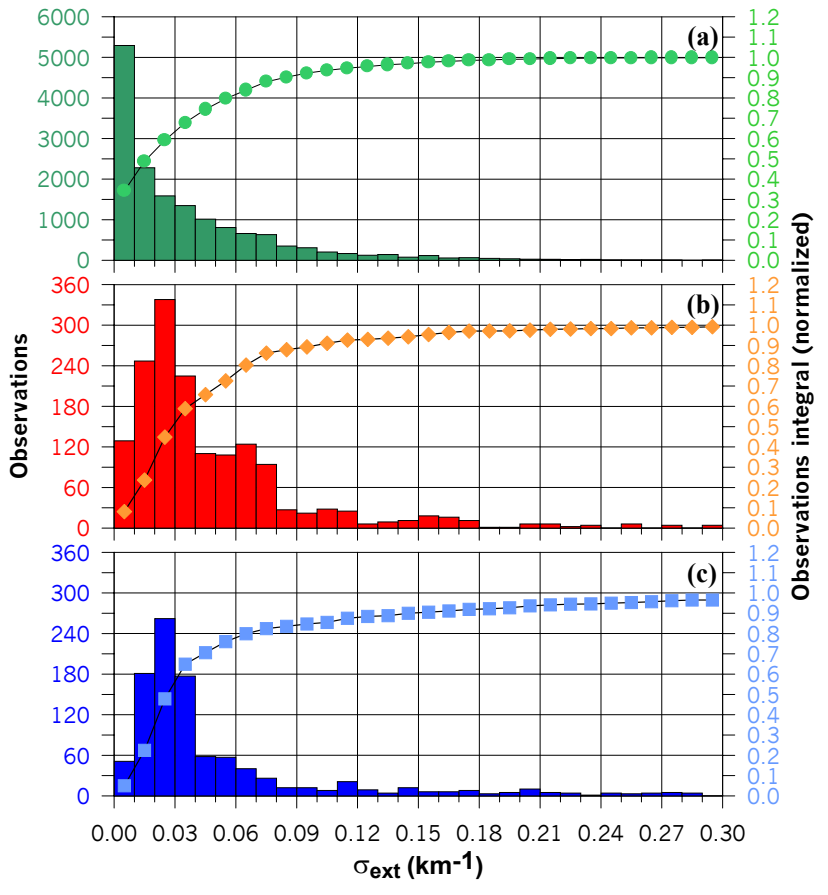

Fig. 14. Frequency of occurrence of the aerosol extinction coefficient values $\left(\sigma_{\text {ext }}\right)$ as measured by lidar (at $532 \mathrm{~nm}$ ) under (a) continental, (b) desert dust, and (c) maritime aerosol conditions at Mediterranean sites. The measured $\sigma_{\text {ext }}$ values were binned with a $0.01 \mathrm{~km}^{-1}$-step. The total number of observations considered is 17436,1586 , and 1332, for continental, desert dust and maritime aerosol, respectively. Note that, due to the typically different vertical displacement of the three aerosol types, $\sigma_{\text {ext }}$ data corresponding to different altitude ranges of the tropospheric lidar profile were considered, i.e. $0<\mathrm{z}<4 \mathrm{~km}$ for continental aerosol, $2 \mathrm{~km}<\mathrm{z}<6 \mathrm{~km}$ for desert dust aerosol and $0 \mathrm{~km}<\mathrm{Z}<2 \mathrm{~km}$ for maritime aerosol.

$\left(\mathrm{km}^{-1}\right)$ (at $\left.532 \mathrm{~nm}\right)$, and volume, $\mathrm{V}\left(\mathrm{cm}^{3} / \mathrm{cm}^{3}\right)$, were computed for size distributions and refractive indices typical of each aerosol type. Each computation was performed randomly choosing the aerosol microphysical parameters (size distribution, refractive index) within appropriate ranges fixed according to data available in literature. In the present study, those $\mathrm{V}$ and $\sigma_{\text {ext }}$ computations were employed to investigate the dependence of the $\alpha$ parameter on $\sigma_{\text {ext }}$ for the three different aerosol types. To start, we will first refer to the mass-to-extinction efficiency for unit density (i.e. $\alpha^{*}$ $\left(\mathrm{m}^{2} / \mathrm{g}\right)=\sigma_{\text {ext }} / \mathrm{V} \cdot \rho$, with $\left.\rho=1 \mathrm{~g} / \mathrm{cm}^{3}\right)$. The outcome of this analysis is given in Fig. 13, where $\alpha^{*}$ is plotted with respect to the relevant $\sigma_{\text {ext }}\left(\mathrm{km}^{-1}\right)$, for each aerosol type. Note that the $0.01 \mathrm{~km}^{-1}$-step $\sigma_{\text {ext }}$ values reported in Fig. 13 were obtained binning the original $20000 \sigma_{\mathrm{ext}}$ data. The corresponding mean $\alpha^{*}$ value associated to each bin is reported with its variability ( \pm 1 standard deviation) in Fig. 13. As can be noticed, due to the different microphysical aerosol properties, a substantially different $\alpha^{*}$ versus $\sigma_{\text {ext }}$ behavior is obtained for the three aerosol types. 
From these general curves, it was then necessary to derive, for each aerosol type, a reliable, mean $\alpha^{*}$ value to be applied as a mass-to-extinction efficiency to the satellite AOT retrievals. This was done by weighting the $\alpha^{*}$ values in Fig. 13 for the actual, i.e. observed, frequency of occurrence of the $\sigma_{\text {ext }}$ values for the three aerosol types. To this purpose, lidar $\sigma_{\text {ext }}$ tropospheric profiles measured at Mediterranean sites under relevant aerosol load conditions were considered. In particular, lidar measurements collected at the outskirts of Rome, Italy $\left(41.8^{\circ} \mathrm{N}, 12.6^{\circ} \mathrm{E}\right)$ during 2001 (Gobbi et al., 2004) were used as representative of continental conditions; lidar measurements recorded at the same site during seven major dust events registered in 2001 were used as representative of transported desert dust conditions; lidar observations performed in Crete $\left(35.5^{\circ} \mathrm{N}, 23.7^{\circ} \mathrm{E}\right)$, Greece in May 1999 (Gobbi et al., 2000) were employed as representative of maritime conditions.

For each case, lidar data of aerosol extinction were binned with $0.01 \mathrm{~km}^{-1}$-step to evaluate the frequency of occurrence of the different $\sigma_{\text {ext }}$ values (only values $\sigma_{\text {ext }}>0.001 \mathrm{~km}^{-1}$ were considered). Due to the typically different vertical displacement of the three aerosol types (e.g. Gobbi et al., 2004), $\sigma_{\text {ext }}$ data corresponding to different altitude ranges of the tropospheric lidar profile were considered, i.e. $0<\mathrm{z}<4 \mathrm{~km}$ for continental aerosol, $2 \mathrm{~km}<\mathrm{Z}<6 \mathrm{~km}$ for desert dust aerosol and $0 \mathrm{~km}<\mathrm{z}<2 \mathrm{~km}$ for maritime aerosol. Overall, a total of 17436,1586 , and $1332 \sigma_{\text {ext }}$ observations were employed for continental, desert dust and maritime aerosol, respectively. The resulting $\sigma_{\text {ext }}$ frequency distributions for the three aerosol types are shown in the histograms of Fig. 14. As can be observed, due to the particles larger size, higher $\sigma_{\text {ext }}$ values are generally registered in desert dust (Fig. 14b) and maritime (Fig. 14c) conditions with respect to the continental case (Fig. 14a). Note however the larger width of the dust $\sigma_{\text {ext }}$ frequency spectra with respect to the maritime case.

Combining results of Fig. 13 with data of Fig. 14, mean $\alpha^{*}$ values for the three aerosol types were derived as $\alpha^{*}=\left[\Sigma_{b i n}\right.$ $\left(\alpha_{b i n}^{*} \cdot\right.$ Observations $\left._{b i n}\right) / \Sigma_{b i n}$ Observations $\left._{b i n}\right]$. These are $\alpha_{\text {cont }}^{*}=5.6 \mathrm{~m}^{2} / \mathrm{g}, \alpha_{\text {dust }}^{*}=3.4 \mathrm{~m}^{2} / \mathrm{g}$ and $\alpha_{\mathrm{mar}}^{*}=3.7 \mathrm{~m}^{2} / \mathrm{g}$ for continental, desert dust and maritime aerosol respectively. From these $\alpha^{*}$ values (as mentioned referred to $\rho=1 \mathrm{~g} / \mathrm{cm}^{3}$ ), the three mass-to-extinction efficiencies were finally obtained as $\alpha_{\text {cont }}=2.80 \mathrm{~m}^{2} / \mathrm{g}, \alpha_{\text {dust }}=1.36 \mathrm{~m}^{2} / \mathrm{g}$ and $\alpha_{\mathrm{mar}}=1.85 \mathrm{~m}^{2} / \mathrm{g}$ considering a particle density $\rho=2.0 \mathrm{~g} / \mathrm{cm}^{3}$ for both continental and maritime aerosols and $\rho=2.5 \mathrm{~g} / \mathrm{cm}^{3}$ for desert dust).

\section{Appendix B: Acronyms}

$\begin{array}{lll}\text { ADEOS } & - & \text { Advanced Earth Observing Satellite } \\ \text { AERONET } & - & \text { Aerosol Robotic Network } \\ \text { ATSR-2 } & - & \text { Along Track Scanning Radiometer 2 } \\ \text { CIRES } & - & \text { Cooperative Institute for Research } \\ & & \text { in Environmental Sciences } \\ \text { EOS } & - & \text { Earth Observing System } \\ \text { ERS2 } & - & \text { European Remote Sensing Satellite } 2 \\ \text { ESA } & - & \text { European Space Agency } \\ \text { FORTH } & - & \text { Foundation for Research and } \\ & & \text { Technology - Hellas } \\ \text { IMS-METU } & - & \text { Institute of Marine Sciences, } \\ & & \text { Middle East Technical University } \\ \text { MISR } & - & \text { Multiangle Imaging Spectro Radiometer } \\ \text { MODIS } & - & \text { Moderate-resolution Imaging } \\ & & \text { Spectroradiometer } \\ \text { NASA } & - & \text { National Aeronautics and Space } \\ & & \text { Administration } \\ \text { NCEP } & - & \text { National Centers for Environmental } \\ & & \text { Prediction } \\ \text { NCAR } & - & \text { National Center for Atmospheric Research } \\ \text { NOAA } & - & \text { National Oceanic and Atmospheric } \\ \text { POLDER } & - & \text { Administration } \\ \text { SeaWiFS } & - & \text { Polarization and Directionality } \\ & & \text { of the Earth Reflectance } \\ \text { Sea-viewing Wide Field-of-view Sensor }\end{array}$

Acknowledgements. The authors would like to thank the MODIS Science Data Support Team and the Earth Observing System Data Gateway for processing and distribution of MODIS data, respectively. We gratefully acknowledge 1) the SeaWiFS Project (Code 970.2) - NASA Goddard Space Flight Center (Greenbelt, Maryland, USA) for providing the true colors images via the website http://seawifs.gsfc.nasa.gov/cgi/seawifs_subreg.pl, and 2) the NOAA-CIRES Climate Diagnostics Center (Boulder, Colorado, USA) for providing the wind field images via the web site http: //www.cdc.noaa.gov.

F. Barnaba performed this study thanks to a grant from the GASTRAN project, funded by the Italian Space Agency (ASI).

Edited by: A. Lambert

\section{References}

Avila, A., Alarcon, M., and Queralt, I.: The chemical composition of dust transported in red rains - its contribution to the biogeochemical cycle of a holm oak forest in Catalonia (Spain), Atmos. Environ., 32, 179-191, 1998.

Barnaba, F. and Gobbi, G. P.: Lidar estimation of tropospheric aerosol extinction, surface area and volume: Maritime and desert-dust cases, J. Geophys. Res., 106 (D3), 3005-3018, 2001.

Barnaba, F. and Gobbi, G. P.: Modeling the aerosol extinction versus backscatter relationship for lidar applications: maritime and continental conditions, J. Atmos. Oc., 21, 428-442, 2004.

Bergametti, G., Dutot, A.-L., Buat-Menard, P., Losno, R., and Remoudaki, E.: Seasonal Variability of the Elemental Composition 
of Atmospheric Aerosol over the Northwestern Mediterranean, Tellus, B, 41, 353-361, 1989.

Cachorro, V. E. and Tanré, D.: The correlation between particle mass loading and extinction: application to desert dust aerosol content estimation, Remot. Sen. E., 60, 187-194, 1997.

Collaud Coen, M., Weingartner, E., Schaub, D., Hueglin, C., Corrigan, C., Schwikowski, M., and Baltensperger, U.: Saharan dust events at the Jungfraujoch: detection by wavelength dependence of the single scattreing albedo and analysis of the events during the years 2001 and 2002, Atmos. Chem. Phys. Discus., 3, 55475594, 2003,

\section{SRef-ID: 1680-7375/acpd/2003-3-5547.}

Chu, D. A., Kaufman, Y. J., Ichoku, C., Remer, L. A., Tanré, D., and Holben, B. N.: Validation of MODIS aerosol optical depth retrieval over land, Geophys. Res. Lett., 29 (12), doi:10.1029/2001GL013205, 2002.

Chu, D. A., Kaufman, Y. J., Zibordi, G., Chern, J. D., Jietai Mao, Chengcai Li, and Holben, B. N.: Global monitoring of air pollution over land from the Earth Observing System-Terra Moderate Resolution Imaging Spectroradiometer (MODIS), J. Geophys. Res., 108, 4661, doi:10.1029/2002JD003179, 2003.

De Tomasi, F., Blanco A., and Perrone, M. R.: Raman lidar monitoring of extinction and backscattering of Africa dust layers and dust characterization, Appl. Optics, 42, 1699-1709, 2003.

Di Sarra, A., Di Iorio, T., Cacciani, M., Fiocco, G., and Fuà, D.: Saharan dust profiles measured by lidar at Lampedusa, J. Geophys. Res., 106, 10 335-10348, 2001.

Dulac, F., Tanré, D., Bergametti, G., Buat-Ménard, P., Desbois, M., and Sutton, D.: Assessment of the african airborne dust mass over the western Mediterranean Sea using meteosat data, J. Geophys. Res., 97, 2489-2506, 1992a.

Dulac, F., Bergametti, G., Losno, R., Remoudaki, E., Gomes, L., Ezat, U., and Buat-Ménard, P.: Dry deposition of mineral aerosol particles in the atmosphere: significance of the large size fraction, in Precipitation, Scavenging and Atmosphere-Surface exchange, edited by: Schwartz, S. E. and Slinn, W. G. N., 841-845, Hemisphere, Bristol, Pa., 1992b.

Dulac, F. and Chazette, P.: Airborne study of a multy-layer aerosol structure in the eastern Mediterranean observed with the airborne polarized lidar ALEX during a STAAARTE campaign (7 June 1997), Atmos. Chem. Phys., 3, 1817-1831, 2003,

SRef-ID: 1680-7324/acp/2003-3-1817.

Dubovik, O., Holben, B. N., Eck, T. F., Smirnov, A., Kaufman, Y. J., King, M. D., Tanré, D., and Slutsker, I.: Variability of absorption and optical properties of key aerosol types observed in worldwide locations, J. Atmos. Sci., 59, 590-608, 2002.

Duncan, B. N. and Bey, I.: A modeling study of the export pathways of pollution from Europe: Seasonal and interannual variations (1987-1997), J. Geophys. Res., 109, D08301, doi:10.1029/2003JD004079, 2004.

Ganor, E., Foner, H. A., Bingemer, H. G., Udisti, R., and Setter, I.: Biogenic sulphate generation in the Mediterranean Sea and ist contribution to the sulphate anomaly in the aerosol over Israel and the eastern Mediterranean, Atmos. Environ., 34, 3453-3462, 2000.

Gobbi, G. P., Barnaba, F., Giorgi, R., and Santacasa, A.: Altituderesolved properties of a Saharan-Dust event over the Mediterranean, Atmos. Environ., 34, 5119-5127, 2000.
Gobbi, G. P., Barnaba, F., and Ammannato, L.: The vertical distribution of aerosol, Saharan dust and cirrus clouds in Rome (Italy) in the year 2001, Atmos. Chem. Phys., 4, 351-359, 2004, SRef-ID: 1680-7324/acp/2004-4-351.

Hamonou, E., Chazette, P., Balis, D., Dulac, F., Schneider, X., Galani, E., Ancellet, G., and Papayannis, A.: Characterization of the vertical structure of Saharan dust export to the Mediterranean basin, J. Geophys. Res., 104, 22 257-22 270, 1999.

Israelevich, P. L., Levin, Z., Joseph, J. H., and Ganor, E.: Desert aerosol transport in the Mediterranean region as inferred from the TOMS aerosol index, J. Geophys. Res., doi:10.1029/2001JD002011, 2002.

Jamet, C., Moulin, C., and Thiria, S.: Monitoring aerosol optical properties over the Mediterranean from SeaWiFS images using a neural network inversion, Geophys. Res. Lett., 31, L13107, doi:10.129/2004GL019951, 2004.

Kalnay, E., Kanamitsu, M., Kistler, R., Collins, W., Deaven, D., Gandin, L., Iredell, M., Saha, S., White, G., Woollen, J., Zhu, Y., Leetmaa, A., Reynolds, B., Chelliah, M., Ebisuzaki, W., Higgins, W., Janowiak, J., Mo, K.C., Ropelewski, C., Wang, J., Jenne, R., and Joseph, D.: The NCEP/NCAR 40-Year Reanalysis Project, Bull. Amer. Meteor. Soc., 77, 437-472, 1996.

Kaufman, Y. J., Tanré, D., Remer, L. A., Vermote, E. F., Chu, A, and Holben, B. N.: Operational remote sensing of tropospheric aerosol over land from EOS Moderate-resolution Imaging Spectroradiometer, J. Geophys. Res., 102, 17 051-17 065, 1997.

Kaufman Y. J. and Tanré, D.: Algorithm for remote sensing of tropospheric aerosol from MODIS, Algorithm Theoretical Basis Documents (ATBD-MOD-02), 85 pp., 1998.

Kaufman, Y. J., Smirnov, A., Holben, B. N., and Dubovik, O.: Baseline maritime aerosol: methodology to derive the optical thickness and the scattering properties, Geophys. Res. Lett., 28, 32513254, 2001.

Kaufman, Y. J., Tanré, D., and Boucher, O.: A satellite view of aerosols in the climate system, Nature, 419, 215-223, 2002.

King, M. D., Kaufman, Y. J., Tanré, D., and Nakajima, T.: Remote sensing of tropospheric aerosol from space: past, present and future, Bull. Amer. Meteor. Soc., 80, 2229-2259, 1999.

Kinne, S., Lohmann, U., Feichter, J., Schulz, M., Timmreck, C., Ghan, S., Easter, R., Chin, M., Ginoux, P., Takemura, T., Tegen, I., Koch, D., Herzog, M., Penner, J., Pitari, G., Holben, B., Eck, T., Smirnov, A., Dubovik, O., Slutsker, I., Tanre, D., Torres, O., Mishchenko, M., Geogdzhayev, I., Chu, D. A., and Kaufman Y.: Monthly averages of aerosol properties: A global comparison among models, satellite data, and AERONET ground data, J. Geophys. Res., 108, 4634, doi:10.1029/2001JD001253, 2003.

Kubilay, N., Nickovic, S., Moulin, C., and Dulac, F.: An illustration of the transport and deposition of mineral dust onto the eastern Mediterranean, Atmos. Environ., 34, 1293-1303, 2000.

Kouvarakis, G., Bardouki, H., and Mihalopoulos, N.: Sulfur budget above the Eastern Mediterranean: relative contribution of anthropogenic and biogenic sources, Tellus, B, 54, 201-212, 2002.

Lelieveld, J., Berresheim, H., Borrmann, S., Crutzen, P. J., Dentener, F. J., Fischer, H. Feichter, J., Flatau, P. J., Heland, J., Holzinger, R., Korrmann, R., Lawrence, M. G., Levin, Z., Markowicz, K. M., Mihalopoulos, N., Minikin, A., Ramanathan, V., de Reus, M., Roelofs, G. J., Scheeren, H. A., Sciare, J., Schlager, H., Schultz, M., Siegmund, P., Steil, B., Stephanou, E. G., Stier, P., Traub,M., Warneke, C., Williams, J., and Ziereis, 
H.: Global air pollution crossroads over the Mediterranean, Science, 298, 794-799, 2002.

Levy, R. C., Remer, L. A., Tanré, D., Kaufman, Y. J., Ichoku, C., Holbe, B. N., Livingston, J. M., Russel, P. B., and Maring, H.: Evaluation of the Moderate-Resolution Imaging Spectroradiometer (MODIS) retrievals of dut aerosol over the ocean during PRIDE, J. Geophys. Res., 108, doi:10.1029/2002JD002460, 2003.

Liu, Y., Sarnat, J. A., Coull, B. A., Koutrakis, P., and Jacob, D. J.: Validation of Multiangle Imaging Spectroradiometer (MISR) aerosol optical thickness measurements using Aerosol Robotic Network (AERONET) observations over the contiguous United States, J. Geophys. Res., 109, doi:10.1029/2003JD003981, 2004.

Loye-Pilot, M. D. and Martin, J. M.: Saharan dust input to the western Mediterranean: An eleven years record in Corsica, in: The Impact of Desert Dust Across the Mediterranean, edited by: Guerzoni, S. and Chester, R. pp. 191-200, Kluwer Acad., Norwell, Mass., 1996.

Mariotti, A., Struglia, M. V., Zeng, N., and Lau, K.-M.: The hydrological cycle in the Mediterranean region and implications for the water budget of the Mediterranean Sea, J. Climate., 15, 1674-1690, 2002.

Molinaroli, E., Guerzoni, S., and Rampazzo, G.: Contribution of Saharan dust to the Central Mditerranean basin, in: Processes controlling the composition of clastic sediments, edited by: Johnsson, M. J. and Basu, A., Boulder, Colorado, Geological Society of America Paper 284, 1993.

Moulin, C., Guillard, F., Dulac, F., and Lambert, C. E., Chazette P., Jankowiak, I., Chatenet, B., and Lavenu, F.: Long-term daily monitoring of Saharan dust load over ocean using Meteosat ISCCP-B2 data 2. Accuracy of the method and validation using sun photometer data, J. Geophys. Res., 102, 16 959-16969, 1997.

Moulin, C., Lambert, C., Dayan, U., Masson, V., Ramonet, M., Bousquet, P., Legrand, M., Balkanski, Y., Guelle, W., Marticorena, B., Bergametti, G., and Dulac, F.: Satellite climatology of African dust transport in the Mediterranean atmosphere, J. Geophys. Res., 103, 13 137-13 144, 1998.

Muller, D., Mattis, I., Wandinger, U., Ansmann, A., Althausen, D., Dubovik, O., Eckhardt S., and Sthol, A.: Saharan dust over a central European EARLINET_AERONET site: Combined observations with Raman lidar and Sun photometer, J. Geophys. Res., 108, 4345, doi:10.1029/2002JD002918, 2003.

Penner, J. E., Andreae, M., Annegarn, H., Barrie, L., Feichter, J., Hegg, D., Jayaraman, A., Leaitch, R., Murphy, D., Nganga, J., and Pitari, G.: Aerosols, their Direct and Indirect Effects. In Climate Change 2001: The Scientific Basis, Cambridge University Press, Cambridge, UK, 2001.

Putaud, J.-P., Raes, F., Van Dingenen, R., Bruggemann, E., Facchini, M. C., Decesari S., Fuzzi, S., Gehrig, R., Huglin, C., Laj, P., Lorbeer, G., Maenhaut, W., Mihalopoulos, N., Muller, K., Querol, X., Rodriguez, S., Schneider, J., Spindler, G., ten Brink, H., Torseth, K., and Wiedensohler, A.: A European aerosol phenomenology - 2: chemical characteristics of particulate matter at kerbside, urban, rural and background sites in Europe, Atmos. Environ., 38, 2579-2595, 2004.

Remer, L. A. and Kaufman, Y. J.: Dynamic aerosol model: Urban/Industrial aerosol, J. Geophys. Res., 103, 13859-13871, 1998.
Remer, L. A., Tanré, D., Kaufmann, Y. J., Ichoku, C., Mattoo, S., Levy, R., Chu, D. A., Holben, B., Dubovik, O., Smirnov, A., Martins, J. V., Li, R.-R., and Ahmad, Z.: Validation of MODIS aerosol retrieval over ocean, Geophys. Res. Lett., 29 (12), doi:10.1029/2001GL013204, 2002.

Robles Gonzales, C., Schaap, M., de Leeuw, G., Builtjes, P. J. H., and van Loon, M.: Spatial variation of aerosol properties over Europe derived from satellite observations and comparison with model clculations, Atmos. Chem. Phys., 3, 521-533, 2003,

SRef-ID: 1680-7324/acp/2003-3-521.

Salisbury, G., Williams, J., Holzinger, R., Gros, V., Mihalopoulos, N., Vrekoussis, M., Sarda-Estève, R., Berresheim, H., Kuhlmann, R., Lawrence, M., and Lelieveld, J.: Ground based PTR-MS measurements of reactive organic compounds during the MINOS campaign in Crete, July-August 2001, Atmos. Chem. Phys., 3, 925-940, 2003,

SRef-ID: 1680-7324/acp/2003-3-925.

Schaap, M., van Loon, M., ten Brink, H. M., Dentener, F. J., and Builtjes, P. J. H.: Secondary inorganic aerosol simulations for Europe with special attention to nitrate, Atmos. Chem. Phys., 4, 857-874, 2004,

SRef-ID: 1680-7324/acp/2004-4-857.

Sciare, J., Bardouki, H., Moulin, C., and Mihalopoulos, N.: Aerosol sources and their contribution to the chemical composition of aerosols in the Eastern Mediterranean Sea during summertime, Atmos. Chem. Phys., 3, 291-302, 2003a,

SRef-ID: 1680-7324/acp/2003-3-291.

Sciare, J., Cachier, H., Oikonomou, K., Ausset, P., Sarda-Estève, R., and Mihalopoulos, N.: Characterization of carbonaceous aerosols during the MINOS campaign in Crete, July-August 2001: a multi-analytical approach, Atmos. Chem. Phys., 3, 1743-1757, 2003b,

\section{SRef-ID: 1680-7324/acp/2003-3-1743.}

Sciarra, R., Volpe, G., and Santoleri, R.: SeaWIFS observations of Saharan dust events over the Mediterranean Sea, Proc. SPIE Int. Soc. Opt. Eng., 5233, 61-68, 2004.

Smirnov, A., Yershov, O., and Villevalde, Y.: Measurement of aerosol optical depth in the Atlantic and Mediterranean Sea, Proc. SPIE Int. Soc. Opt. Eng., 2582, 203-214, 1995.

Smirnov, A., Holben, B. N., Kaufman, Y. J., Dubovik, O., Eck, T. F., Slutsker, I., Pietras, C., and Halthore, R. N.: Optical properties of atmospheric aerosol in maritime environments, J. Atmos. Sci., 59, 501-523, 2002.

Stohl, A., Eckhardt, S., Forster, C., James, P., and Spichtinger, N.: On the pathways and timescales of intercontinental air pollution transport, J. Geophys. Res., 107, 4684, doi:10.1029/2001JD001396, 2002.

Tanré, D., Bréon, F. M., Deuzé, J. L., Herman, M., Goloub, P., Nadal, F., and Marchand, A.: Global observations of anthropogenic aerosols from satellite, Geophys. Res. Lett., 28, 45554558, 2001.

Van Dingenen, R., Raes, F., Putaud, J.-P., Baltensperger, U., Charron, A., Facchini, M. C., Decesari, S., Fuzzi, S., Gehrig, R., Hansson, H.-C., Harrison, R. M., Huglin, C., Jones, A. M., Laj, P., Lorbeer, G., Maenhaut, W., Palmgren, F., Querol, X., Rodriguez, S., Schneider, J., ten Brink, H., Tunved, P., Torseth, K., Wehner, B., Weingartner, E., Wiedensohler, A., and Wahlin, P.: A European aerosol phenomenology - 1: physical characteristics of particulate matter at kerbside, urban, rural and background 
sites in Europe, Atmos. Environ., 38, 2561-2577, 2004.

Wang, J. and Christopher, S. A.: Intercomparison between satellitederived aerosol optical thickness and $\mathrm{PM}_{2.5}$ mass: Implications for air quality studies, Geophys. Res. Lett., 30, 2095, doi:10.1029/2003GL18174, 2003. 